\title{
New insights into the subglacial and periglacial hydrology of Vatnajökull, Iceland, from a distributed physical model
}

\author{
Gwenn E. FLOWERS, ${ }^{*}$ Helgi BJÖRnSSON, Finnur PÁLSSON \\ Science Institute, University of Iceland, Dunhaga 3, IS-107 Reykjavik, Iceland \\ E-mail:flowers@geop.ubc.ca
}

\begin{abstract}
We apply a time-dependent distributed glaciohydraulic model to Vatnajökull ice cap, Iceland, aiming to determine the large-scale subglacial drainage structure, the importance of basally derived meltwater, the influence of a permeable glacier bed and Vatnajökull's discharge contribution to major rivers in Iceland. The model comprises two coupled layers that represent the subglacial horizon perched on a subsurface aquifer in the western sector and bedrock in the eastern sector. To initialize and drive the simulations, we use digital elevation models of the ice surface and bed, the 1999/2000 measured mass balance and an estimate of subglacial geothermal heat fluxes. The modelled subglacial flow field differs substantially from that derived by hydraulic-potential calculations, and the corresponding distribution of basal effective pressure shows a strong correlation between low effective pressure and surge-prone areas in northeastern and southern sectors of Vatnajökull. Simulations suggest that geothermally derived basal melt may account for up to $\sim 5 \%$ of the annual glacial discharge, and buried aquifers may evacuate up to $\sim 30 \%$ of subglacial water. Time-dependent tests yield estimates of the glacial discharge component in various outlet rivers and suggest a possible seasonal migration of subglacial hydraulic divides. This study of present-day Vatnajökull hydrology forms the starting point for investigations of its future evolution.
\end{abstract}

\section{INTRODUGTION}

The hydrology of Vatnajökull is a subject of long-standing scientific interest and of practical importance for Iceland. It has attracted the attention of scientists studying jökulhlaups, or outburst floods (e.g. Björnsson, 1974, 1976, 1978, 1988, 1992; Nye, 1976; Spring and Hutter, 1981; Fowler, 1999; Roberts and others, 2000; Björnsson and others, 2001; Jóhannesson, 2002), glacier-bed mechanics (e.g. Boulton and Hindmarsh, 1987) and fast-flowing ice (e.g. Björnsson, 1998; Fuller and Murray, 2002). Vatnajökull feeds most of Iceland's large rivers (Fig. 1) and is the source of the most destructive jökulhlaups in recent decades (e.g. Gudmundsson and others, 1997).

Studies of Vatnajökull's regional-scale hydrology over the last 15 years (e.g. Björnsson, 1982, 1986a, 1988) have relied on detailed topographic data and static subglacial fluid-potential calculations using the method of Shreve (1972, 1985). This "hydraulic-potential method" has been used to delineate subglacial drainage basins and predict flood routing from subglacial lakes in western Vatnajökull (e.g. Björnsson, 1978, 1986a). While the hydraulic-potential method captures the first-order geometric controls on subglacial drainage, it takes no account of spatial and temporal variations in water supply. Furthermore, it does not include the potentially important effect of a permeable subglacial

* Present address: Department of Earth and Ocean Sciences, University of British Columbia, 2219 Main Mall, Vancouver, British Columbia V6T 1Z4, Canada. substrate. To construct a dynamic description of Vatnajökull hydrology, we apply recent advances in theoretical modelling along with Vatnajökull field data. In particular, we adapt the glaciohydraulic model of Flowers and Clarke (2002) to Vatnajökull. Digital elevation models (DEMs) of the ice surface and bed (Björnsson, 1986b, 1988; Science Institute, University of Iceland, unpublished data) define the glacier geometry, and the surface forcing is derived from 1999/2000 measured mass balance (Pálsson and others, 2001). Subsurface hydrogeologic properties are estimated based on the geological map of Iceland (Jóhannesson and others, 1990) and a review paper of Sigurðsson (1990).

The objectives of this study are (1) to compare the modelled subglacial drainage structure of Vatnajökull to that obtained by the hydraulic potential method, (2) to quantify the contribution of geothermally derived meltwater to glacier runoff, (3) to estimate glacial discharge through subsurface aquifers and (4) to constrain the glacial contributions to major rivers originating at Vatnajökull. This study forms the basis for an investigation of Vatnajökull geometry and hydrology in response to future climate, undertaken with both ice-dynamical and hydrological models.

\section{METHODS}

We consider a two-layer coupled model for water flow at the glacier bed and in an underlying aquifer. Surface and basal water are sources to the subglacial drainage system, and water exchange between the subglacial and ground-water systems acts as a source or sink depending on the direction of water flow. Each system is treated as a vertically 


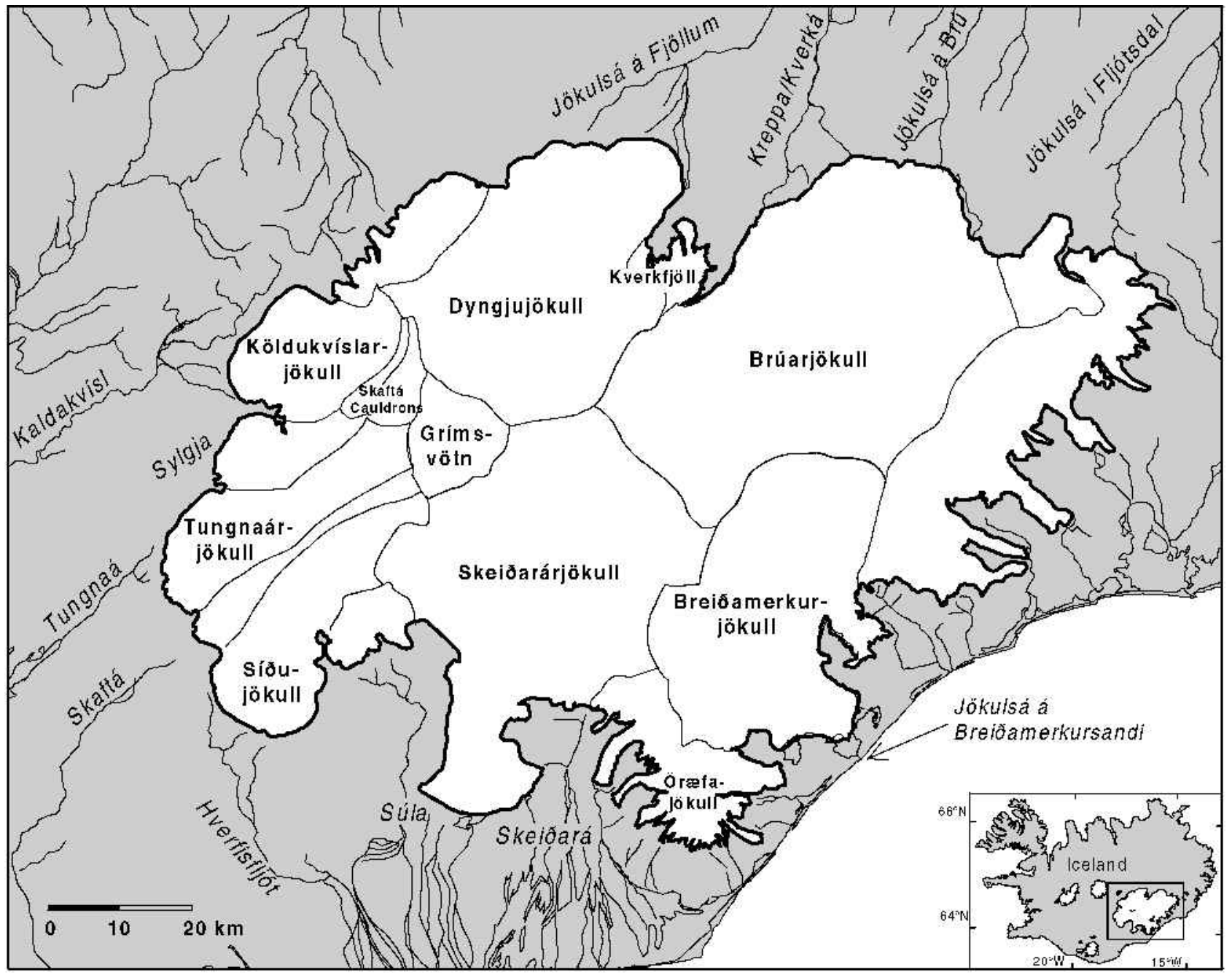

Fig. 1. Location map of Vatnajökull and its major outlet rivers. Ice divides are shown to delineate major outlet glaciers.

integrated layer governed by a local water balance (Flowers and Clarke, 2002). In this section we briefly outline the model theory. Superscript s is reserved for variables associated with subglacial drainage, and superscript a for those associated with the aquifer.

\subsection{Subglacial drainage}

The ablation area of Vatnajökull drains largely through conduit networks. On rare occasions, most notably during jökulhlaups from Grímsvötn beneath Skeiðarárjökull, these channels extend tens of kilometres into the centre of the ice cap. However, successful hydrological predictions have been made assuming subglacial water pressure is equivalent to the ice overburden pressure (e.g. Björnsson, 1982, 1986a), suggesting that Vatnajökull drainage cannot be wholly conduit-dominated. More precisely, even in a conduit system the subglacial water pressure on a regional scale is likely to be higher than the pressure in the conduit itself, as conduits occupy a small areal fraction of any given region and have a finite spatial influence (e.g. Hubbard and others, 1995). Where they exist, conduits would carry most of the discharge, but the basal hydraulic potential field would be jointly controlled by conduit flow and flow through the system feeding the conduits.

Following standard glaciological theory, we expect conduit networks to develop where and when there is a suffi- cient supply of surface water (see Paterson, 1994, ch. 6, for a review). Hence the area serviced by conduits expands and contracts seasonally. Changes in the extent of the conduit network are mirrored by changes in a slower "distributed" system. These morphological transitions in the subglacial drainage system also occur in conjunction with surge onset and termination (e.g. Kamb and others, 1985; Björnsson, 1998). Such complexities present a substantial modelling challenge, especially as a conduit theory that is readily imported into continuum models has not yet been published.

One end-member formulation of basal drainage would be to construct a conduit network and solve the equations of conduit growth and decay in response to water input (e.g. Arnold and others, 1998). This approach requires a priori specification of the drainage-system structurewhich is substantially more difficult for an entire ice cap than for an individual valley glacier - leaving only the temporal (rather than spatial) evolution of the drainage system undetermined. Whereas a continuum approach would allow some crude approximation of morphological transitions in the basal drainage system (from fast to slow, and vice versa), the conduit-based approach cannot emulate the slow distributed drainage that takes place over most of the ice cap unless it is coupled to a distributed model. The choice between these two end-member approaches depends on the goals of the study. For determining mid- to late-melt season discharge hydrographs, the conduit approach is 
superior despite the quantity of prior information required and its associated uncertainty. For investigating seasonal drainage-system transitions, objectively determining basal water routing, and relating basal hydraulics to dynamics with quantities such as effective pressure, the more flexible continuum approach is preferable.

Treatment of the subglacial system outlined below assumes that drainage takes place in a macroporous sediment horizon at the glacier bed (Flowers and Clarke, 2002). This morphology lends itself to continuum mathematics, while enabling a wide range of hydrological behaviour. Changes in water flux are accommodated by adjustments in porosity, as is possible for dilatant materials such as glacial till (e.g. Clarke, 1987). The glacier bed is assumed to be at the pressure-melting point. We introduce the notion of fast (conduitlike) and slow (distributed) drainage systems (Raymond and others, 1995) by allowing subglacial hydraulic conductivity, the controlling parameter in this formulation of subglacial transport, to vary with subglacial water-sheet thickness.

For an incompressible fluid, conservation of mass leads to the subglacial water balance

$$
\frac{\partial h^{\mathrm{s}}}{\partial t}+\frac{\partial Q_{j}^{\mathrm{s}}}{\partial x_{j}}=\dot{b}^{z_{\mathrm{B}}}+\dot{b}^{z_{\mathrm{S}}}-\phi^{\mathrm{s}: \mathrm{a}},
$$

where $x_{j}$ is the horizontal spatial coordinate, $h^{\mathrm{s}}(x, y, t)$ is the subglacial water thickness, $Q_{j}^{\mathrm{s}}$ is water flux, $\dot{b}^{z_{\mathrm{B}}}$ is the basal source term that includes melting due to geothermal heat and glacier sliding friction, $\dot{b}^{z_{\mathrm{S}}}$ is the surface water infiltration rate to the bed, and $\phi^{\text {s:a }}$ represents water exchange with the underlying aquifer. In this study, we do not have sufficient knowledge of basal sliding rates to include the frictional component of $\dot{b}^{z_{\mathrm{B}}}$, so

$$
\dot{b}^{z_{\mathrm{B}}}=Q_{\mathrm{G}} /\left(\rho_{\mathrm{I}} L\right)
$$

is strictly a function of the geothermal heat flux $Q_{\mathrm{G}}$, ice density $\rho_{\mathrm{I}}=910 \mathrm{~kg} \mathrm{~m}^{-3}$ and latent heat of fusion of ice $L=$ $3.34 \times 10^{5} \mathrm{~J} \mathrm{~kg}^{-1}$. We treat surface water as a direct source to the glacier bed, $\dot{b}^{z_{\mathrm{s}}}$, rather than explicitly modelling its transport through the ice. This introduces substantial computational savings, and is justified insofar as water delivery to the bed is efficient. For a model with gridcells $\geq 1 \mathrm{~km}^{2}$ applied to the temperate and low-sloping ice cap Vatnajökull, efficient delivery of surface water through moulins and crevasses is a reasonable assumption below the equilibrium line. Surface water that originates above the equilibrium-line altitude (ELA) is routed to the appropriate model gridcell below the ELA in a predefined supraglacial drainage network. This network is derived using a steepest-descent algorithm that connects each interior pixel to an outlet point (e.g. Zevenbergen and Thorne, 1987; Tarboton, 1997). A similar strategy of surface water routing was used successfully by Arnold and others (1998) in a multicomponent hydrology model of Haut Glacier d'Arolla, Switzerland.

As for Darcian flow, we write the vertically integrated water flux in Equation (1) as

$$
Q_{j}^{\mathrm{s}}=-\frac{K^{\mathrm{s}} h^{\mathrm{s}}}{\rho_{\mathrm{w}} g} \frac{\partial \psi^{\mathrm{s}}}{\partial x_{k}},
$$

with a homogeneous and isotropic hydraulic conductivity $K^{\mathrm{s}}$ and fluid potential $\psi^{\mathrm{s}}=p^{\mathrm{s}}+\rho_{\mathrm{w}} g z_{\mathrm{B}}$, where $p^{\mathrm{s}}$ is water pressure, $\rho_{\mathrm{w}}=1000 \mathrm{~kg} \mathrm{~m}^{-3}, g=9.81 \mathrm{~m} \mathrm{~s}^{-2}$ and $z_{\mathrm{B}}$ is bed elevation. Mathematical closure requires a relationship for $p^{\mathrm{S}}$ as a function of $h^{\mathrm{s}}$. We use

$$
p^{\mathrm{s}}\left(h^{\mathrm{s}}\right)=p_{\mathrm{I}}\left(h^{\mathrm{s}} / h_{\mathrm{c}}^{\mathrm{s}}\right)^{\frac{7}{2}}
$$

(Flowers, 2000), where $p_{\mathrm{I}}=\rho_{\mathrm{I}} g h_{\mathrm{I}}$ with ice thickness $h_{\mathrm{I}}=z_{\mathrm{S}}-z_{\mathrm{B}}$, and $h_{\mathrm{c}}^{\mathrm{s}}$ is the critical thickness of the water sheet (porosity $\times$ layer thickness) corresponding to buoyancy pressure $\left(p^{\mathrm{s}}=p_{\mathrm{I}}\right)$. We allow hydraulic conductivity to fluctuate in space and time as a function of $h^{\mathrm{s}}$ according to

$$
\begin{aligned}
\log \left(K^{\mathrm{s}} / K\right) & =\frac{1}{\pi}\left[\log \left(K_{\max }^{\mathrm{s}} / K\right)-\log \left(K_{\min }^{\mathrm{s}} / K\right)\right] \\
& \cdot \arctan \left[k_{\mathrm{a}}\left(\frac{h^{\mathrm{s}}}{h_{\mathrm{c}}^{\mathrm{s}}}-k_{\mathrm{b}}\right)\right] \\
& +\frac{1}{2}\left[\log \left(K_{\max }^{\mathrm{s}} / K\right)+\log \left(K_{\min }^{\mathrm{s}} / K\right)\right],
\end{aligned}
$$

where $K=1 \mathrm{~m} \mathrm{~s}^{-1}$ is introduced to non-dimensionalize the argument of the logarithm, $k_{\mathrm{a}}$ modulates the abruptness of the transition from $K_{\min }^{\mathrm{s}}$ to $K_{\max }^{\mathrm{s}}$ and $k_{\mathrm{b}}$ determines its position (Flowers and Clarke, 2002).

\subsection{Subsurface ground-water flow}

The balance equation for the aquifer analogous to Equation (1) is

$$
\left(\frac{h^{\mathrm{a}}}{\rho^{\mathrm{a}}}\right) \frac{\partial \rho^{\mathrm{a}}}{\partial t}+\frac{\partial h^{\mathrm{a}}}{\partial t}+\frac{\partial Q_{j}^{\mathrm{a}}}{\partial x_{j}}=\phi^{\mathrm{s}: \mathrm{a}}
$$

(Flowers and Clarke, 2002). For a depth-independent aquifer porosity $n^{\mathrm{a}}$, the water thickness in the aquifer $h^{\mathrm{a}}$ is defined as $n^{\mathrm{a}}\left(z_{\mathrm{w}}-z_{\mathrm{L}}\right)$, where $z_{\mathrm{w}}$ and $z_{\mathrm{L}}$ are the elevations of the saturated horizon and the lower boundary of the aquifer, respectively. Fluid compressibility effects are included in the variable water density $\rho^{\text {a }}$ which obeys the equation of state

$$
\rho^{\mathrm{a}}=\rho_{\mathrm{w}} \exp \left(\beta p^{\mathrm{a}}\right)
$$

with $\beta=5.04 \times 10^{-10} \mathrm{~Pa}^{-1}$ and $p^{\mathrm{a}}$ the water pressure in the aquifer. Ground-water flux is written analogously to Equation (3) as

$$
Q_{j}^{\mathrm{a}}=-\frac{K^{\mathrm{a}} h^{\mathrm{a}}}{\rho_{\mathrm{w}} g} \frac{\partial \psi^{\mathrm{a}}}{\partial x_{k}},
$$

with fluid potential $\psi^{\mathrm{a}}=p^{\mathrm{a}}+\rho_{\mathrm{w}} g z_{\mathrm{L}}$. Density $\rho_{\mathrm{w}}$ is used in Equation (8), rather than $\rho^{\mathrm{a}}$, because $Q^{\mathrm{a}}$ appears as the argument of a spatial derivative in Equation (6) and we assume that $\left(Q_{j}^{\mathrm{a}} / h^{\mathrm{a}}\right)\left(\partial \rho^{\mathrm{a}} / \partial x_{j}\right) \ll\left(\partial \rho^{\mathrm{a}} / \partial t\right)$.

Equation (6) governs both saturated and unsaturated flow in the aquifer. When the aquifer is unsaturated, the water table is a free surface, so $\left(\partial \rho^{\mathrm{a}} / \partial t\right)=0$. Saturation implies that $\left(\partial h^{\mathrm{a}} / \partial t\right) \approx 0$. For the unsaturated case,

$$
p^{\mathrm{a}}=\rho_{\mathrm{w}} g h^{\mathrm{a}} \quad h^{\mathrm{a}}<n^{\mathrm{a}} d^{\mathrm{a}},
$$

with $n^{\mathrm{a}}$ and $d^{\mathrm{a}}$ the aquifer porosity and thickness, respectively. For the saturated case,

$$
p^{\mathrm{a}}=\rho_{\mathrm{w}} g h^{\mathrm{a}}+\frac{h^{\mathrm{a}}-n^{\mathrm{a}} d^{\mathrm{a}}}{\alpha^{\mathrm{a}} d^{\mathrm{a}}},
$$

where $\alpha^{\mathrm{a}}$ is the aquifer compressibility and Equation (10) is derived for vertical stresses on an aquifer (see Freeze and Cherry, 1979, p. 57) due to changes in water content (Flowers and Clarke, 2002).

\subsection{Water exchange}

To avoid the complexities of a three-dimensional model, we parameterize the exchange between the subglacial sheet and underlying aquifer $\phi^{\text {s:a }}$. Cast in terms of dependent variables $h^{\mathrm{s}}$ and $h^{\mathrm{a}}, \phi^{\text {s:a }}$ evolves simultaneously with both 
Table 1. Physical constants and numerical parameters

\begin{tabular}{lll}
\hline Parameter & Value & Definition \\
\hline Physical constants: & \\
$\rho_{\mathrm{w}}$ & $1000 \mathrm{~kg} \mathrm{~m}^{-3}$ & Density of water at $0^{\circ \mathrm{C}}$ \\
$\rho_{\mathrm{I}}$ & $910 \mathrm{~kg} \mathrm{~m}^{-3}$ & $\begin{array}{l}\text { Density of ice } \\
g\end{array}$ \\
$\beta$ & $9.81 \mathrm{~m} \mathrm{~s}^{-2}$ & Gravitational acceleration \\
$L$ & $5.04 \times 10^{-10} \mathrm{~Pa}^{-1}$ & Compressibility of water \\
Numerical parameters: & Latent heat of fusion of ice \\
$L_{x}$ & $150 \mathrm{~km}$ & \\
$L_{y}$ & $107 \mathrm{~km}$ & Model domain, zonal \\
$\Delta x$ & $1 \mathrm{~km}$ & Model domain, meridional \\
$\Delta y$ & $1 \mathrm{~km}$ & Zonal grid spacing \\
$\Delta t$ & $1-5 \mathrm{~h}$ & Meridional grid spacing \\
& & Maximum time-step \\
\hline
\end{tabular}

systems. For saturated and unsaturated conditions in the aquifer, respectively,

$$
\phi^{\mathrm{s}: \mathrm{a}}= \begin{cases}\frac{K_{\mathrm{t}}}{\rho_{\mathrm{w}} g d_{\mathrm{t}}}\left[\left(p^{\mathrm{s}}-p^{\mathrm{a}}\right)+\rho_{\mathrm{w}} g d_{\mathrm{t}}\right] & h^{\mathrm{a}} \geq n^{\mathrm{a}} d^{\mathrm{a}} \\ \frac{K_{\mathrm{t}}}{\rho_{\mathrm{w}} g d_{\mathrm{t}}}\left[p^{\mathrm{s}}+\rho_{\mathrm{w}} g d_{\mathrm{t}}\right] & h^{\mathrm{a}}<n^{\mathrm{a}} d^{\mathrm{a}},\end{cases}
$$

where $K_{\mathrm{t}}$ and $d_{\mathrm{t}}$ are the vertical conductivity and thickness of the debris layer (aquitard) separating the basal hydraulic system from the aquifer. This is analogous to a system of interbedded aquifers and aquitards where flow is horizontal in the aquifers and vertical in the aquitards (Bredehoeft and Pinder, 1970). The quantity $\rho_{\mathrm{w}} g d_{\mathrm{t}}$ represents the driving potential due to elevation differences between the glacier bed and the top surface of the aquifer. For the purpose of calculating $\phi^{\text {s:a }}$, fluid pressure at the top surface of the aquifer is required. Thus, in the saturated case, the first term in Equation (10) is dropped and $p^{\mathrm{a}}=\left(h^{\mathrm{a}}-n^{\mathrm{a}} d^{\mathrm{a}}\right) / \alpha^{\mathrm{a}} d^{\mathrm{a}}$. In the unsaturated case (Equation (9)), the top surface of the aquifer is unpressurized, so $p^{\mathrm{a}}=0$. Both positive and negative values of $\phi^{\text {s:a }}$ are permitted, corresponding to aquifer infiltration and exfiltration, respectively.

\subsection{Model numerics}

For Vatnajökull the zonal $\left(L_{x}\right)$ and meridional $\left(L_{y}\right)$ limits of the model domain are approximately $18^{\circ} 20^{\prime}-15^{\circ} 20^{\prime} \mathrm{W}$ and $63^{\circ} 55^{\prime}-65^{\circ} 00^{\prime} \mathrm{N}$, respectively. This area is discretized into $n_{x} \times n_{y}=150 \times 107$ Cartesian gridcells, resulting in grids of size $\Delta x=\Delta y=1 \mathrm{~km}$. Equations (1) and (6) are solved simultaneously on identical grids for $2 \times n_{x} \times n_{y}=32100$ unknown variables. Boundary conditions on the subglacial system $\left(p^{\mathrm{s}}=0\right)$ are imposed at the ice margin. Boundary conditions on the ground-water system are imposed distal from the ice cap at the grid edge. We assume the aquifer is well drained, hence $h^{\mathrm{a}}=0$ at the grid boundary. Physical and numerical parameters are listed in Table 1.

Conventional finite-difference approximations are used to discretize the governing equations, with second-order centred differences in space and forward differences in time. We use a staggered numerical grid (see Patankar, 1980) where scalar quantities (e.g. $h^{\mathrm{s}}$ ) are evaluated at cell-centred nodes and vectors (e.g. $Q_{j}^{\mathrm{s}}$ ) are evaluated across cell interfaces. Gradients of scalars then apply to cell interfaces and divergence of vectors to cell-centred nodes, which leads to a more realistic representation of the flux field and thus a more stable numerical scheme. Dependent variables $h^{\mathrm{s}}$ and $h^{\mathrm{a}}$ are represented as an equal blend of implicit (future) and
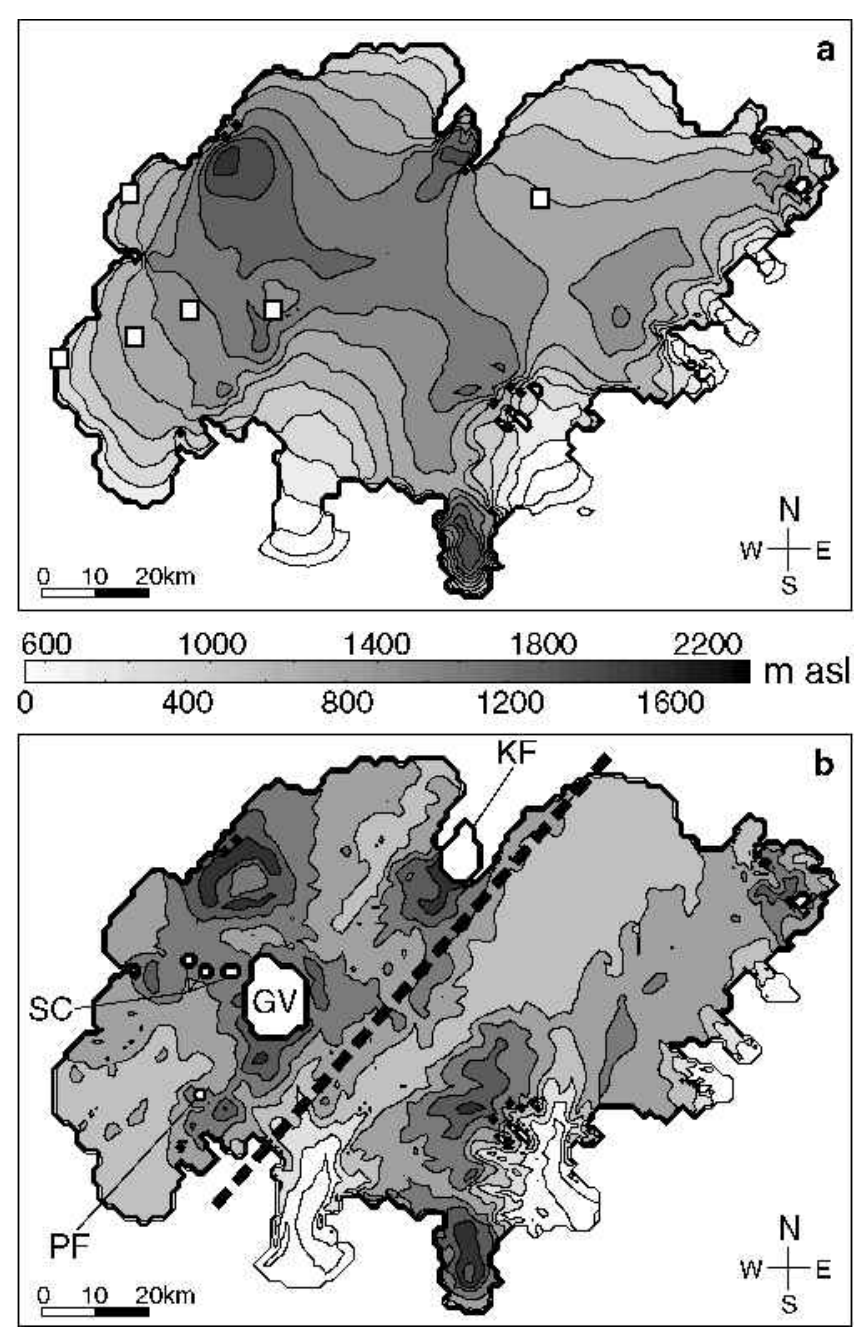

Fig. 2. DEMs $(1 \times 1 \mathrm{~km}$ pixels). (a) Glacier surface. Squares denote locations of automatic weather stations. (b) Glacier bed topography. Subglacial geothermal areas are labelled ( KF, Kverkfjöll; SC, Skaftá Cauldrons; GV, Grimsvötn; PF, Pálsfjall). Dashed line partitions permeable (west) and impermeable (east) regions of the glacier bed.

explicit (present) values in all terms but the time derivatives. This partitioning is known as the Crank-Nicolson scheme, and serves to reduce the order of the error in the time discretization (Fletcher, 1991). A Newton-Krylov procedure is used to solve the resulting sparse system of equations. The problem is linearized in the outer iteration, and the linear system is solved with a preconditioned biconjugate gradient algorithm (Press and others, 1992, p. 77-82).

\section{INPUTS AND IMPLEMENTATION}

Model initialization requires DEMs of the ice surface and bed, distributions of surface and basal melt rates and a variety of model parameters that define the vertical dimensions and properties of each system. Below we outline the sources and preprocessing of these inputs.

\subsection{Ice-cap geometry}

Radio-echo sounding data collected on Vatnajökull since 1976 have been processed and merged into high-resolution $(200 \times 200 \mathrm{~m})$ DEMs of the glacier surface and bed (Björnsson, 1986b, 1988; Björnsson and Einarsson, 1991; Science 


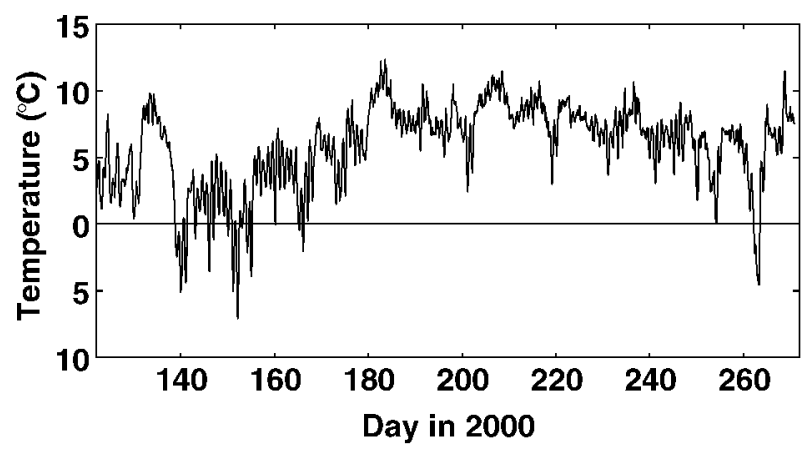

Fig. 3. Synthetic sea-level temperature record, May-September 2000, constructed from five AWS air-temperature time series (station locations in Fig. 2a).

Institute, University of Iceland, unpublished data). For this study we generate more computationally convenient DEMs by averaging each separate $5 \times 5$ pixel cluster into a single value. Figure 2 plots the resulting representation of Vatnajökull topography.

The model domain is partitioned along a geological boundary (Fig. 2b) roughly separating permeable Quaternary basalts to the west from nearly impermeable Tertiary deposits to the east (Jóhannesson and others, 1990). The permeability contrast between these formations is several up to eight orders of magnitude (personal communication from F. Sigurðsson, 2002). The ground-water equation (6) is only solved in the western (permeable) sector, where we assume the aquifer to be of uniform thickness and subparallel to the glacier bed.

\subsection{Geothermal heat flux}

Geothermal heat flux is a potentially important source of meltwater beneath Vatnajökull. A heat-flux gradient striking northwest--southeast surrounds the ice cap, with the highest background fluxes $\left(0.20-0.25 \mathrm{~W} \mathrm{~m}^{-2}\right)$ overlying the active rift zone that divides Iceland (Flóvenz and Sæmundsson, 1993). Much higher localized values of heat flux (up to $\sim 50 \mathrm{~W} \mathrm{~m}^{-2}$ ) are found coincident with individual central volcanoes. In the absence of a subglacial heat-flux map, a uniform background value of $0.18 \mathrm{~W} \mathrm{~m}^{-2}$ is assigned to the eastern sector of Vatnajökull. In the western sector, subsurface hydrothermal circulation is believed to be sufficiently vigorous to prevent heat from reaching the base of the ice (personal communication from Ó. G. Flóvenz, 2001). Active geothermal areas beneath western Vatnajökull (Fig. 2b) are assigned values in $\mathrm{W} \mathrm{m}^{-2}$ as follows (Björnsson, 1988): Kverkfjöll, 30; Skaftá Cauldrons, 50; Grímsvötn/Grímsfjall, 50; Pálsfjall, 10. Geothermal heat flux $Q_{\mathrm{G}}$ is related to the basal melt rate by Equation (2).

\subsection{Mass balance, $1999-2000$}

Digital models of Vatnajökull winter $\left(b_{\mathrm{w}}\right)$ and summer $\left(b_{\mathrm{s}}\right)$ balances for the glacial year 1999/2000 have been constructed to match the $(200 \times 200 \mathrm{~m})$ DEM grid (Pálsson and others, 2001). The net balance $b_{\mathrm{n}}=b_{\mathrm{w}}+b_{\mathrm{s}}$ of the ice cap was $-0.85 \mathrm{~m}$ for 1999/2000. Digital balance models with $150 \times 107$ pixels are created in the manner described for the DEMs.

From these balance distributions we compute the mean summer $\left(\dot{b}_{\mathrm{s}}^{z_{\mathrm{S}}}\right)$ and annual $\left(\dot{b}_{\mathrm{a}}^{z_{\mathrm{S}}}\right)$ surface melt rates as

$$
\begin{aligned}
& \dot{b}_{\mathrm{s}}^{z_{\mathrm{S}}}=\operatorname{MAX}\left(0,-b_{\mathrm{s}}\right) / t_{\mathrm{s}} \\
& \dot{b}_{\mathrm{a}}^{z_{\mathrm{s}}}=\operatorname{MAX}\left(0,-b_{\mathrm{n}},-b_{\mathrm{s}}\right) / t_{\mathrm{a}},
\end{aligned}
$$

with $t_{\mathrm{s}}=5$ months (May-September) and $t_{\mathrm{a}}=1$ year.
Negative signs are used in Equations (12) and (13) to generate positive melt rates. These melt rates are minimum estimates as they do not include snow deposited and melted within the same measurement interval (e.g. May-September or October-April).

\subsection{Surface-melt time series}

In the absence of spatially dense measurements of surface melt rate, we utilize observed temperature records from summer 2000 to construct a time series of the surface melt rate for each model gridcell. The degree-day method (e.g. Braithwaite and Olesen, 1989), which assumes a proportionality between positive temperature and ablation, provides a ready means of estimating melt rates from air-temperature measurements. Provided we know the ablation totals of snow and ice and can construct a spatially variable temperature record, we need only assume a proportionality between the degree-day factors (DDFs) for snow and ice in order to estimate surface melt rates in each gridcell.

Six automatic weather stations (AWSs), ranging in elevation from 755 to $1724 \mathrm{~m}$ (see Fig. 2a), provide $2 \mathrm{~m}$ air temperatures for May-September 2000. We use splines to map these records onto a common time axis, and a linear regression to compute a lapse rate at each hourly time-step. All lapse rates are then averaged to obtain a single value for the whole interval. Six sea-level temperature time series are constructed by applying this calculated lapse rate $\left(4.5^{\circ} \mathrm{C} \mathrm{km}^{-1}\right)$ to the original data. Figure 3 shows the result of averaging these time series after they have been adjusted to sea level (using the calculated lapse rate) to obtain a single synthetic sea-level temperature record. For modelling purposes, this reconstruction describes the temporal variation of air temperature. Spatial variations are introduced through the calculated lapse rate and the distribution of glacier surface elevations. Correspondence between observed and computed temperatures for the six AWS locations is reasonable, with standard deviations of $0.8-1.7^{\circ} \mathrm{C}$.

To compute time-dependent surface melt rates, we determine DDF values that produce the correct snow and ice

\begin{tabular}{|c|c|c|}
\hline Parameter & Value & Definition \\
\hline \multicolumn{3}{|c|}{ Surface ablation } \\
\hline$\lambda$ & 0.75 & $\mathrm{DDF}^{\text {snow }} / \mathrm{DDF}^{\mathrm{ice}}$ \\
\hline \multicolumn{3}{|c|}{ Subglacial sediment sheet } \\
\hline$h_{\mathrm{c}}^{\mathrm{s}}$ & $1.0 \mathrm{~m}$ & Critical water-sheet thickness \\
\hline$K_{\min }^{\mathrm{s}}$ & $1 \times 10^{-7} \mathrm{~ms}^{-1}$ & Minimum hydraulic conductivity \\
\hline$K_{\max }^{\mathrm{s}}$ & $1 \times 10^{-1} \mathrm{~ms}^{-1}$ & Maximum hydraulic conductivity \\
\hline$k_{\mathrm{a}}$ & 100 & $K^{\mathrm{s}}\left(h^{\mathrm{s}}\right)$ scaling parameter \\
\hline$k_{\mathrm{b}}$ & 0.85 & $K^{\mathrm{s}}\left(h^{\mathrm{s}}\right)$ scaling parameter \\
\hline \multicolumn{3}{|c|}{ Till properties } \\
\hline$d^{\mathrm{t}} P P^{2}$ & $1.0 \mathrm{~m}$ & Thickness \\
\hline$K^{\mathrm{t}}$ & $1 \times 10^{-9} \mathrm{~ms}^{-1}$ & Hydraulic conductivity \\
\hline \multicolumn{3}{|c|}{ Aquifer properties } \\
\hline$n^{\mathrm{a}} d^{\mathrm{a}}$ & $25.0 \mathrm{~m}$ & Porosity $\times$ thickness \\
\hline$K^{\mathrm{a}}$ & $1 \times 10^{-2} \mathrm{~ms}^{-1}$ & Hydraulic conductivity \\
\hline$\alpha^{\mathrm{a}}$ & $1 \times 10^{-9} \mathrm{~Pa}^{-1}$ & Compressibility \\
\hline
\end{tabular}

Table 2. Physical model parameters 

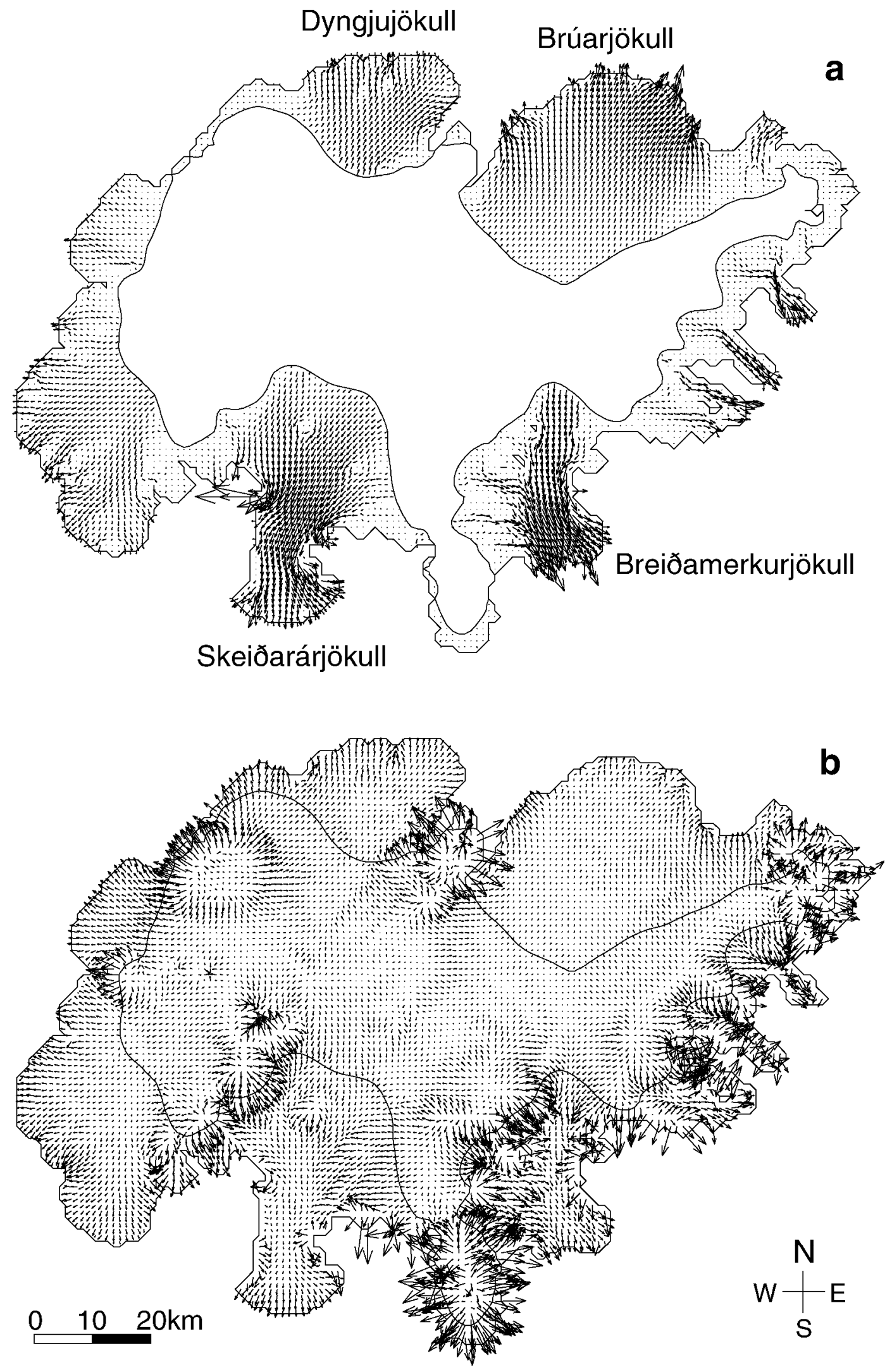

Fig. 4. Subglacial drainage structure. Interior contour is the equilibrium line. (a) Dynamic model steady-state. (b) Static model ( hydraulic-potential method). Vectors are parallel and proportional to the fluid potential gradient.

ablation totals $\left(A^{\text {snow }}\right.$ and $\left.A^{\text {ice }}\right)$ in each gridcell. For cells with $A^{\text {ice }}(i, j)=0$,

$$
\operatorname{DDF}^{\text {snow }}(i, j)=\frac{A^{\text {snow }}(i, j)}{\Delta t_{\mathrm{T}} \sum_{t=1}^{N} \operatorname{MAX}(0, T(i, j, t))},
$$

and for cells with $A^{\text {snow }}(i, j)=0$,

$$
\operatorname{DDF}^{\text {ice }}(i, j)=\frac{A^{\mathrm{ice}}(i, j)}{\Delta t_{\mathrm{T}} \sum_{t=1}^{N} \operatorname{MAX}(0, T(i, j, t))},
$$


with $\Delta t_{\mathrm{T}}=3600 \mathrm{~s}$ and $T(i, j, t)$ the reconstructed temperature vector of length $N . A^{\text {snow }}$ and $A^{\text {ice }}$ are computed as functions of the measured mass balance as

$$
\begin{aligned}
A^{\text {snow }} & = \begin{cases}\operatorname{MAX}\left(0,-b_{\mathrm{s}}\right) & b_{\mathrm{n}}>0 \\
\operatorname{MAX}\left(0, b_{\mathrm{w}}\right) & b_{\mathrm{n}} \leq 0\end{cases} \\
A^{\text {ice }} & =\left\{\begin{array}{cc}
0 & b_{\mathrm{n}}>0 \\
-b_{\mathrm{n}} & b_{\mathrm{n}} \leq 0 .
\end{array}\right.
\end{aligned}
$$

$A^{\text {snow }}$ is a minimum estimate of the total snow ablation since it does not include snow deposited and melted within the same mass-balance measurement interval.

For gridcells with $A^{\text {snow }}(i, j)>0$ and $A^{\text {ice }}(i, j)>0$, we take $\operatorname{DDF}^{\text {snow }}(i, j)=\lambda \operatorname{DDF}^{\text {ice }}(i, j)$ with $\lambda<1$. Assuming that snow melts to completion in any cell $(i, j)$ before ice ablation begins,

$$
\begin{aligned}
\operatorname{DDF}^{\text {snow }}(i, j) & =\frac{A^{\text {snow }}(i, j)}{\Delta t_{\mathrm{T}} \sum_{t=1}^{M} \operatorname{MAX}(0, T(i, j, t))} \\
\operatorname{DDF}^{\text {ice }}(i, j) & =\frac{A^{\text {ice }}(i, j)}{\Delta t_{\mathrm{T}} \sum_{t=M+1}^{N} \operatorname{MAX}(0, T(i, j, t))},
\end{aligned}
$$

where $M$ is a time index that marks the transition from snow ablation to ice ablation. Setting $\operatorname{DDF}^{\text {snow }}(i, j)=$ $\lambda \operatorname{DDF}^{\text {ice }}(i, j)$ yields an equation in $M$ :

$$
\lambda \frac{A^{\text {ice }}(i, j)}{A^{\text {snow }}(i, j)}=\frac{\sum_{t=M+1}^{N} \operatorname{MAX}(0, T(i, j, t))}{\sum_{t=1}^{M} \operatorname{MAX}(0, T(i, j, t))} .
$$

We choose $\lambda=0.75$ to match the highest value calculated from the literature (Laumann and Reeh, 1993), to reflect the relatively mild climate (and hence warm snowfall) of Vatnajökull. For Sátujökull, an outlet of Hofsjökull ice cap, interior Iceland, Jóhannesson and others (1995) report values leading to $\lambda=0.73$. $M$ is then determined for each gridcell such that Equation (20) is satisfied, and DDFs are then back-calculated from Equations (18) and (19). These values are used in conjunction with the reconstructed sealevel temperature curve and calculated lapse rate to estimate the surface melt rate as a function of space and time.

\section{RESULTS AND DISGUSSION}

We present steady-state simulations for the isolated subglacial system, followed by simulations that include geothermal heat flux, ground-water drainage and time-dependent surface ablation. Physical model parameters are listed in Table 2.

\subsection{Steady-state subglacial hydrology}

The 1999/2000 mean annual surface-melt distribution is used to force steady-state simulations of Vatnajökull subglacial drainage. Meltwater above the ELA is routed over the glacier surface, as described earlier, before it is deposited at the glacier bed in the ablation area.

\subsubsection{Subglacial flow field}

The modelled subglacial flow field is plotted in Figure $4 \mathrm{a}\left(Q_{j}^{\mathrm{s}}\right.$, Equation (1)). Intensified subglacial drainage is suggested in basins with vigorous surface melt and large ablation areas, such as Brúarjökull and Skeiðarárjökull. These two outlets,

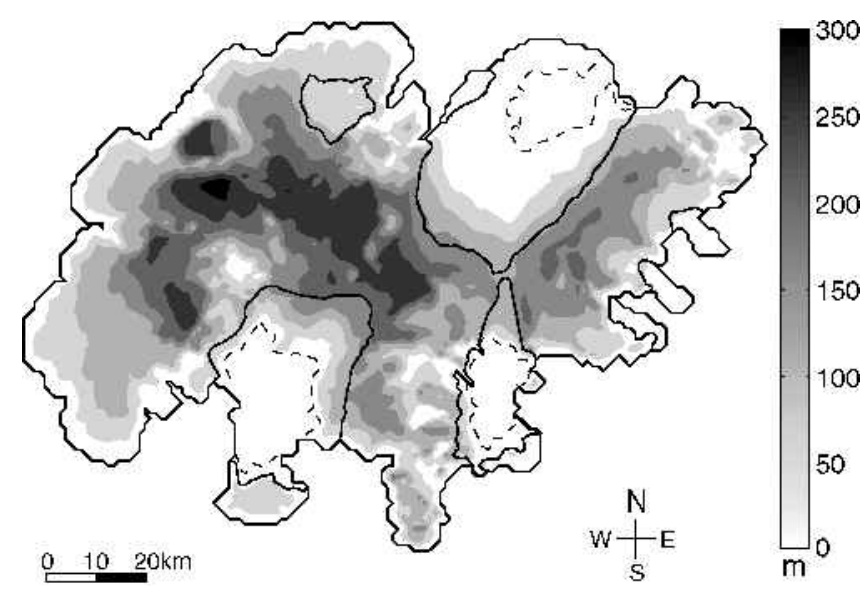

Fig. 5. Simulated steady-state effective pressure $p_{\mathrm{E}}=p_{\mathrm{I}}-p^{\mathrm{s}}$ expressed in metres of water. The $p_{\mathrm{E}}=0$ contour is shown as a dashed line for the simulation forced by the mean annual surface melt rate, and as a solid line for a simulation forced by the summer surface melt rate.

along with Dyngjujökull and Breiðamerkurjökull, are Vatnajökull's most hydraulically active. Modelled flow convergence near the ice margin in Figure 4a highlights possible outlet locations for sub-basin-scale drainage networks. Nearly all of these implied outlets can be associated with actual river tributaries, except in areas with recent surface lava flows. Figure $4 \mathrm{~b}$ is the hydraulic-potential gradient vector field with basal water pressure assumed to be equal to the ice overburden pressure: $\nabla \psi=\rho_{\mathrm{I}} g \nabla z_{\mathrm{S}}+\left(\rho_{\mathrm{w}}-\rho_{\mathrm{I}}\right) g \nabla z_{\mathrm{B}}$, where $\rho_{\mathrm{I}}$ and $\rho_{\mathrm{w}}$ are the densities of ice and water, and $z_{\mathrm{S}}$ and $z_{\mathrm{B}}$ are glacier surface and bed elevations. This vector field is used to determine the subglacial catchment structure of Vatnajökull from which Pálsson and others (2001) estimate glacier runoff to various rivers. While hydraulic-potential analysis is useful for identifying water divides, comparison between Figure $4 \mathrm{a}$ and $\mathrm{b}$ emphasizes the importance of a realistic basal water-pressure distribution (and hence a consideration of water supply) in imaging the large-scale subglacial drainage structure.

\subsubsection{Subglacial effective pressure}

Effective pressure is defined as the difference between the ice overburden pressure and basal water pressure, $p_{\mathrm{E}}=p_{\mathrm{I}}-p^{\mathrm{s}}$. Because it affects basal shear stress and sediment shear strength, it is the hydrological metric most often used in laws for glacier sliding and bed deformation (e.g. Kamb, 1970; Iverson and others, 1999; Kavanaugh, 2000; Tulaczyk and others, 2000). Figure 5 shows the simulated steady-state effective pressure for Vatnajökull.

Drainage basins of Brúarjökull, Skeiðarárjökull and Breiðamerkurjökull contain significant areas of low effective pressure that expand in response to the increased summer melt rate. A common feature of these three outlets is low basal and surface topography, and, in the cases of Skeiðarárjökull and Breiðamerkurjökull, deep bedrock trenches in the ablation area. The area enclosed by the dashed contour resembles the extent of Vatnajökull affected by surges of Brúarjökull, Skeiðarárjökull and Breiðamerkurjökull (Thórarinsson, 1969; Science Institute, University of Iceland, unpublished data). Areas affected by surging are smaller than the total ice catchment basins, especially in the case of Breiðamerkurjökull which only experiences surges in its eastern sector. 
Table 3. Comparison of 1999/2000 glacier runoff to selected outlet rivers as estimated with static (Pálsson and others, 2001) and dynamic models

\begin{tabular}{lcc}
\hline River & \multicolumn{2}{c}{ Discharge } \\
& Static model & Dynamic model \\
& $\mathrm{m}^{3} \mathrm{~s}^{-1}$ & $\mathrm{~m}^{3} \mathrm{~s}^{-1}$ \\
\hline J. á Breiðamerkursandi & 56.8 & 55.1 \\
Tungnaá & 16.4 & 15.2 \\
Sylgja & 5.2 & 7.5 \\
Kaldakvísl & 22.8 & 22.3 \\
Kreppa/Kverká & 27.4 & 37.2 \\
Jökulsá á Brú & 105.2 & 89.2 \\
Jökulsá í Fljótsdal & 12.8 & 11.9 \\
\end{tabular}

This is the first plausible and spatially variable subglacial effective-pressure distribution computed for Vatnajökull. Standard fluid potential calculations assume $p^{\mathrm{s}}=p_{\mathrm{I}}$ and result in a uniform distribution $p_{\mathrm{E}}=0$. Assuming $p^{\mathrm{S}} \propto p_{\mathrm{I}}$ but $p^{\mathrm{s}}<p_{\text {I }}$ yields an effective-pressure distribution that reflects the ice thickness and bears little resemblance to Figure 5.

\subsubsection{Glacier runoff}

Table 3 compares annual glacial discharge contributions to various outlet rivers as estimated with static and dynamic models. The static model (Pálsson and others, 2001) uses measured mass balance and subglacial catchment structure, as determined by the hydraulic-potential method, to compute glacier runoff. The dynamic model, as described in this paper, makes no assumptions about subglacial catchment structure. For each river basin, the glacier runoff estimated with the dynamic model is the sum of simulated discharge from each ice-marginal gridcell.

Agreement between statically and dynamically modelled discharges is good forJökulsá á Breiðamerkursandi, Tungnaá, Kaldakvísl and Jökulsá í Fljótsdal. The Sylgja catchment area is poorly resolved with $1 \mathrm{~km}^{2}$ gridcells, hence the dynamically modelled discharge is less reliable than for the larger outlets.
The discrepancy between statically and dynamically modelled discharges for Jökulsá á Brú and Kreppa/Kverká is strictly a function of catchment divides. Considered together, the discharge sum of the two rivers is approximately the same in both cases.

\subsubsection{Contributions from basal melt}

By including calculated basal melt rates in the simulations, we can evaluate the influence of geothermal heat flux on drainage under Vatnajökull, and comment on the provenance of outlet river discharge. This is relevant to hydrochemical studies of Vatnajökull (e.g. Björnsson and Kristmannsdóttir, 1984), as water derived from the bed has a chemical signature distinct from that of surface water. Table 4 summarizes steady-state subglacial discharge to major outlet rivers as predicted by simulations with and without basal melt. Although geothermally derived meltwater is known to drain episodically in jökulhlaups from Vatnajökull, these simulations assume continuous meltwater drainage and hence highlight all possible routes for basal water. At least one study asserts that more basal meltwater drains from Vatnajökull than is accounted for in jökulhlaups (personal communication from F. Sigurðsson, 2001), raising questions as to the quantity and drainage routes of this additional water.

Although simulated discharge perturbations caused by introducing basal melt cannot be directly equated to geothermally derived discharge, they give some indication of how basal melt might be distributed among the outlets. To compute true provenance fractions would require a tracer transport model. The mean annual discharge due to surface melt from Vatnajökull is calculated to be $\sim 570 \mathrm{~m}^{3} \mathrm{~s}^{-1}$ for 1999/2000. Björnsson and others (1998) estimate the discharge for a zero net-balance year to be $486 \mathrm{~m}^{3} \mathrm{~s}^{-1}$.

For both annual and summer simulations, Jökulsá á Fjöllum experiences the largest absolute change in discharge, $\sim 8 \mathrm{~m}^{3} \mathrm{~s}^{-1}$, when basal melt is included. Tungnaá, Sylgja, Kaldakvísl and Jökulsá á Fjöllum all register annual differences over $10 \%$. All rivers that appear to be appreciably affected by basal melt tap into geothermal systems beneath western Vatnajökull. Rivers draining the eastern sector (Jökulsá á Breiðamerkursandi, Jökulsá á Brú, Jökulsá í Fljóts-

Table 4. Simulated glacial discharge contributions to selected outlet rivers with and without basal melt (1999/2000). Fökulhlaup physics is not included in the model, so simulations with basal melt represent continuous, rather than episodic, drainage of geothermally derived water

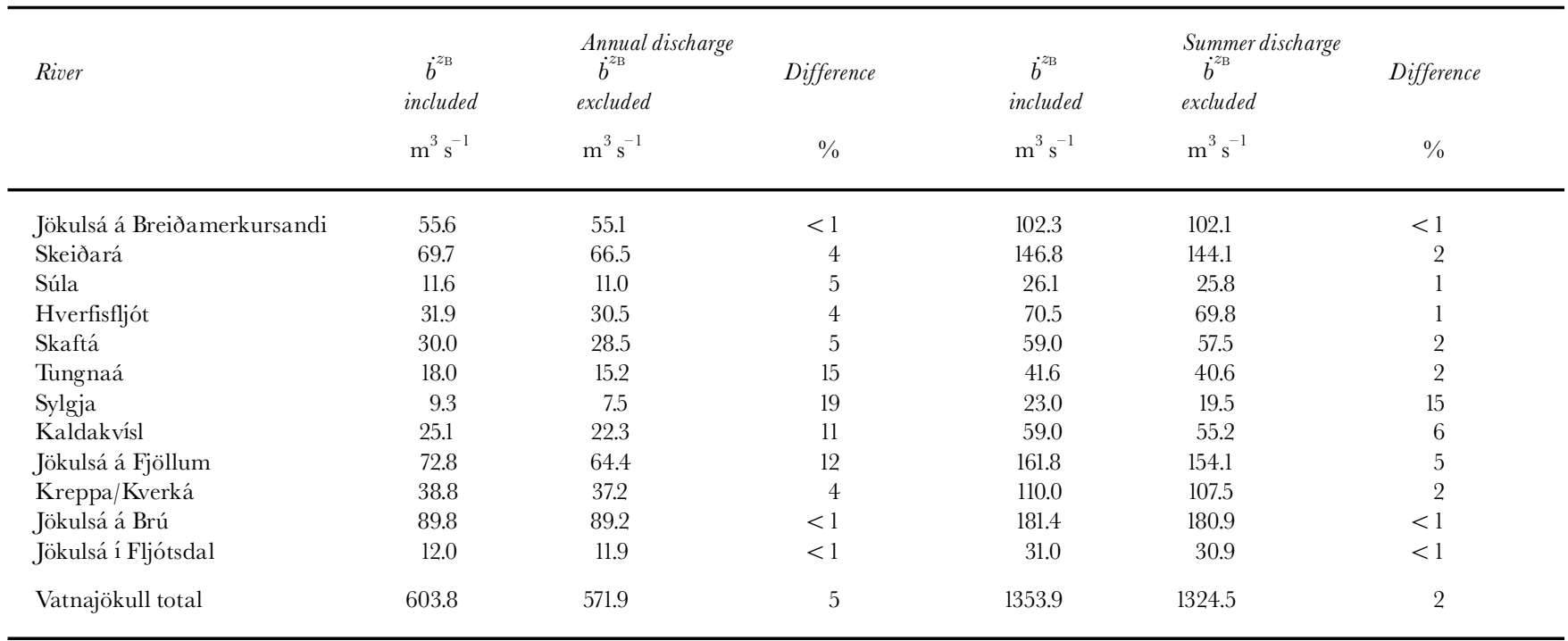




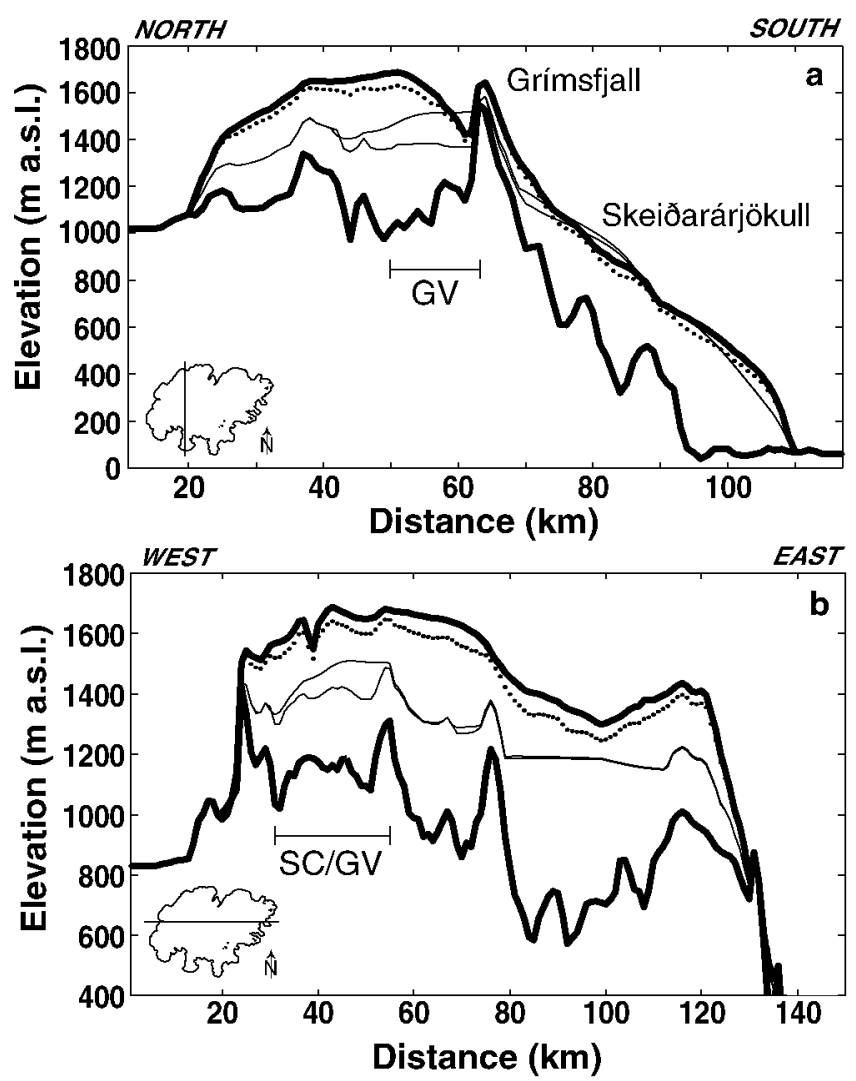

Fig. 6. Profiles of hydraulic head with (solid line) and without (dashed line) geothermal heat sources for a steady-state simulation forced by the mean annual surface melt rate. Solid and dashed lines overlap except above geothermal areas. Glacier surface and bed topography are shown (bold lines) along with hydrostatic head (dotted line). (a) North-south transect through Grimsvötn ( $G V)$ and down Skeiðarárjökull. (b) East-west transect through Skaftá Cauldrons (SC) and north Grimsvötn ( $G V)$.

dal) discharge negligible quantities of basal melt. Hence the background heat flux in the east is not particularly important for Vatnajökull hydrology, even on annual time-scales.

Figure 6 shows perturbations to subglacial hydraulichead profiles caused by geothermal heat sources. The effect of meltwater production at Grímsvötn (Fig. 6a) is localized over the geothermal area, except for a small difference in hydraulic head on upper Skeiðarárjökull. Since we are not modelling subglacial lakes, the elevation of the ice over Grímsvötn is misrepresented in the profile, and should be higher by an amount roughly equivalent to the lake depth. A similar localization of basal meltwater is shown in the transverse profile (Fig. 6b) which intersects the Skaftá Cauldrons and north Grímsvötn.

\subsection{Steady-state coupled hydrology}

Springs in the vicinity of Vatnajökull, particularly north of Dyngjujökull (feedingJökulsá á Fjöllum), attest to the presence of an active ground-water system (Sigurðsson, 1990). Glacially derived ground-water has been detected tens of kilometres from the ice margin, and ground-water recharge by Iceland's four largest ice caps has been estimated at $\sim 130-220 \mathrm{~m}^{3} \mathrm{~s}^{-1}$ (Sigurðsson, 1990). Using the coupled subglacial-subsurface drainage model, we make independent estimates of the glacial contribution to ground-water drainage beneath western Vatnajökull.
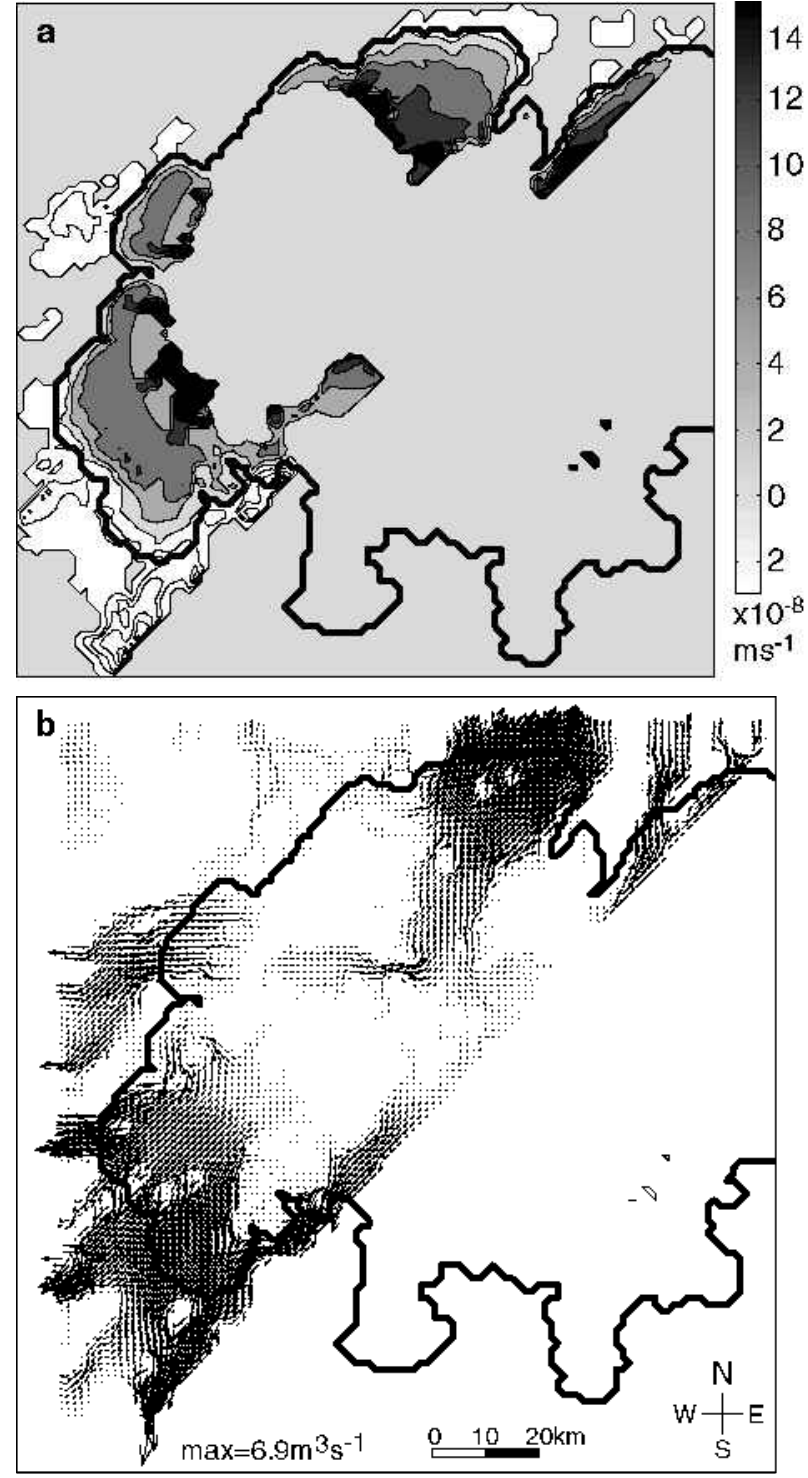

Fig. 7. Ground-water reference equilibrium forced by the mean annual surface melt rate. (a) Modelled vertical water exchange with the glacier bed ( $\phi^{\mathrm{s}: \mathrm{a}}$, Equation (11)). Positive values represent aquifer recharge. (b) Modelled horizontal ground-water flow field. Vector lengths are proportional to discharge magnitude through the aquifer and are oriented parallel to the flow field.

A lack of complete hydrogeologic information for the area requires that we make the simplest possible assumptions. The aquifer is taken to be of uniform thickness and parallel to the glacier bed, and the hydraulic conductivity homogeneous and isotropic. Unless otherwise noted, simulations use parameters in Table 2 and are forced by the 1999/ 2000 surface melt rate.

Figure 7 shows steady-state distributions of water exchange with the aquifer (Equation (3)) and the corresponding ground-water flow field. The pattern of exchange in Figure 7 a persists through simulations with a variety of parameter values. It is characterized by aquifer recharge beneath most of the glacier ablation area, and ground-water expulsion near the glacier margin and in the periglacial area. Bright areas are suggestive of springs and are to be found along the northern margin of Dyngjujökull, west of Köldukvíslarjökull and to the southwest of Tungnaárjökull and Síðujökull. The most vigorous predicted ground-water expulsion 
Table 5. Simulated 1999/2000 subglacial and ground-water discharge to various rivers for two ground-water scenarios: conservative $\left(n^{\mathrm{a}} d^{\mathrm{a}}=25 \mathrm{~m}, K^{\mathrm{a}}=10^{-3} \mathrm{~ms}^{-1}\right)$ and maximum $\left(n^{\mathrm{a}} d^{\mathrm{a}}=50 \mathrm{~m}, K^{\mathrm{a}}=10^{-2} \mathrm{~m} \mathrm{~s}^{-1}\right)$. Results represent a steady state forced by the mean annual surface melt rate

\begin{tabular}{|c|c|c|c|c|c|c|}
\hline River & $\begin{array}{c}Q^{\mathrm{s}} \\
\mathrm{m}^{3} \mathrm{~s}^{-1}\end{array}$ & $\begin{array}{l}\text { Conserva } \\
\qquad Q^{\mathrm{a}} \\
\mathrm{m}^{3} \mathrm{~s}^{-1}\end{array}$ & $\frac{Q^{\mathrm{a}}}{Q^{\mathrm{a}}+Q^{s}}$ & $\begin{array}{c}Q^{\mathrm{s}} \\
\mathrm{m}^{3} \mathrm{~s}^{-1}\end{array}$ & $\begin{array}{c}\text { Maxim } \\
Q^{\mathrm{a}} \\
\mathrm{m}^{3} \mathrm{~s}^{-1}\end{array}$ & $\frac{Q^{\mathrm{a}}}{Q^{\mathrm{a}}+Q^{\mathrm{s}}}$ \\
\hline Jökulsá á Breiðamerkursandi & 55.5 & 0.0 & 0.0 & 55.3 & 0.0 & 0.0 \\
\hline Skeiðará & 67.1 & 0.0 & 0.0 & 64.3 & 0.0 & 0.0 \\
\hline Súla & 11.1 & 0.0 & 0.0 & 10.5 & 0.0 & 0.0 \\
\hline Hverfisfljót & 27.8 & 5.0 & 0.2 & 15.9 & 41.5 & 0.7 \\
\hline Skaftá & 23.7 & 5.6 & 0.2 & 6.7 & 29.0 & 0.8 \\
\hline Tungnaá & 11.1 & 2.6 & 0.2 & 3.3 & 6.7 & 0.7 \\
\hline Sylgja & 5.0 & 2.3 & 0.3 & 1.2 & 0.2 & 0.1 \\
\hline Kaldakvísl & 14.8 & 6.6 & 0.3 & 6.5 & 16.6 & 0.7 \\
\hline Jökulsá á Fjöllum & 53.9 & 11.7 & 0.2 & 16.9 & 68.5 & 0.8 \\
\hline Kreppa/Kverká & 34.2 & 3.2 & 0.1 & 25.5 & 8.5 & 0.3 \\
\hline Jökulsá á Brú & 88.9 & 0.8 & 0.0 & 87.2 & 6.6 & 0.1 \\
\hline Jökulsá í Fljótsdal & 12.0 & 0.0 & 0.0 & 12.0 & 0.0 & 0.0 \\
\hline Vatnajökull total & 535.2 & 43.1 & 0.1 & 421.0 & 187.9 & 0.3 \\
\hline
\end{tabular}

coincides with the river basins Skaftá and Hverfisfljót, but the latter is partially an artifact of the prescribed aquifer boundary. Compared to a map of known spring areas (see Sigurðsson, 1990, fig. 2) our results show artesian conditions over relatively short distances from the glacier margin. This is a result of modelling ground-water transport in homogeneous isotropic horizontal lava beds and neglecting the highly conductive anisotropic fissures.

In Figure $7 \mathrm{a}$, the gray-scale limits $\left(-5\right.$ to $\left.10 \mathrm{~m} \mathrm{~s}^{-1}\right)$ correspond to annual recharge rates of -1.6 to $3.2 \mathrm{~m} \mathrm{a}^{-1}$, but the maximum modelled recharge rate is $7.6 \mathrm{~m} \mathrm{a}^{-1}$. For comparison, Sigurðsson (1990) argues that the subglacial geology may permit recharge rates of 3-4 $\mathrm{m} \mathrm{a}^{-1}$, but that rapid subglacial water transport in ice conduits probably limits these to $1.5^{-}$ $2 \mathrm{ma}^{-1}$. Since our continuum model assumes extensive contact between basal water and the substrate, we regard the simulated recharge rates as maximum estimates. Integrating recharge rate over ice-cap area, we obtain a simulated total volumetric recharge rate beneath the glacier of $118 \mathrm{~m}^{3} \mathrm{~s}^{-1}$. This is consistent with Sigurðsson's (1990) estimate of 50$100 \mathrm{~m}^{3} \mathrm{~s}^{-1}$ of volumetric recharge in the basins of Tungnaá and Jökulsá á Fjöllum alone. The simulated total volumetric expulsion rate from the aquifer to the surface outside of the ice cap is $40 \mathrm{~m}^{3} \mathrm{~s}^{-1}$.

Despite the prescription of an isotropic aquifer conductivity, the simulated ground-water flow field (Fig. 7b) has a dominant northeast-southwest orientation roughly aligned with the geologic strike of the substrata. Modelled water transport in the aquifer is intensified beneath Dyngjujökull in the north and Tungnaárjökull and Síðujökull in the southwest, with topographically driven channelization occurring distal from the glacier. Modelled flow directions in the aquifer are similar to those at the glacier bed, but exhibit less small-scale spatial variability. For hydraulic conductivities $\leq 10^{-4} \mathrm{~m} \mathrm{~s}^{-1}$ in the aquifer, the model predicts ground-water transport to be negligible compared to subglacial drainage.

For different prescribed values of aquifer thickness $d^{\mathrm{a}}$, the spatial extent of ground-water expulsion to the surface would be expanded (for thin aquifers) or reduced (for thick aquifers). Increasing $n^{\mathrm{a}} d^{\mathrm{a}}$ to $50 \mathrm{~m}$ would reduce the bright areas surrounding western Vatnajökull in Figure $7 \mathrm{~b}$ to a small isolated patch along the southern margin (in front of Síðujökull). The ground-water flow field as shown in Figure 7b would appear more topographically channelized if the aquifer were thicker. Linear increases in the transport capacity of the aquifer (through increases in $n^{\mathrm{a}}, d^{\mathrm{a}}$ or $K^{\mathrm{a}}$ ) result in a quadratic decline of the fraction of total runoff discharged from the ice--bed interface rather than through the subsurface. The sensitivity of individual drainage basins to changes in $n^{\mathrm{a}} d^{\mathrm{a}}$ appears to be directly controlled by the subglacial catchment fractions underlain by permeable formations.

Simulated subglacial $\left(Q^{\mathrm{s}}\right)$ and subsurface $\left(Q^{\mathrm{a}}\right)$ discharges to the major outlet rivers are recorded in Table 5 for conservative and maximum estimates of aquifer properties. In the maximum model, five of twelve river basins are dominantly ground-water-fed $\left(Q^{\mathrm{a}} /\left(Q^{\mathrm{a}}+Q^{\mathrm{s}}\right)>0.5\right)$. In the conservative scenario, all western Vatnajökull river basins, from Jökulsá á Fjöllum in the north to Hverfisfljót in the south, have subsurface discharge fractions $\geq 0.15$. Glacierwide, the aquifer transports $\sim 7 \%$ and $\sim 30 \%$, respectively, of the total discharge in the conservative and maximum model simulations.

Sigurðsson (1990) illustrates the effect of ground-water drainage beneath Vatnajökull by comparing Jökulsá á Fjöllum and Jökulsá á Brú, whose drainage basins are situated on permeable and impermeable formations, respectively. $\mathrm{He}$ notes that both rivers carry approximately $150 \mathrm{~m}^{3} \mathrm{~s}^{-1}$ when leaving the glacially influenced ground-water basins, but that the winter base flow in Jökulsá á Brú is $\sim 5-10 \mathrm{~m}^{3} \mathrm{~s}^{-1}$ compared to $\sim 50 \mathrm{~m}^{3} \mathrm{~s}^{-1}$ in Jökulsá á Fjöllum. Our reference model simulations for 2000 predict summer runoff rates from Jökulsá á Fjöllum andJökulsá á Brú to be 154 and $181 \mathrm{~m}^{3} \mathrm{~s}^{-1}$, respectively, and annual runoff rates to be approximately equal around $90 \mathrm{~m}^{3} \mathrm{~s}^{-1}$. The simulated mean annual ground-water discharge, which can be compared to Sigurðsson's (1990) winter base flow estimate, is $\sim 5 \mathrm{~m}^{3} \mathrm{~s}^{-1}$ for Jökulsá á Brú and $\sim 60 \mathrm{~m}^{3} \mathrm{~s}^{-1}$ for Jökulsá á Fjöllum.

These simulations provide only a rough estimate of the large-scale drainage budget of Vatnajökull. Ground-water drainage in the vicinity of Vatnajökull is undoubtedly affected by spatial variations in hydrogeologic properties, which have been entirely neglected in this analysis. The most important 

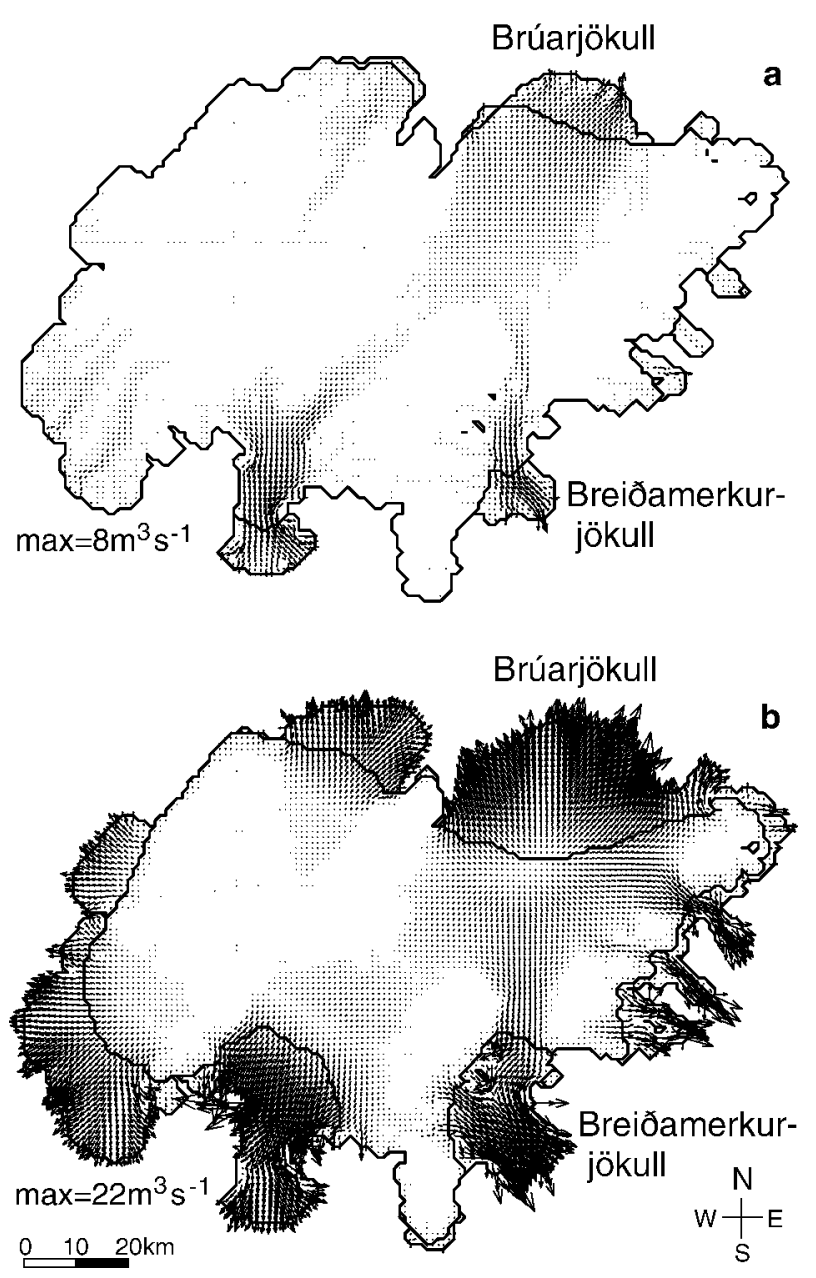

Fig. 8. Snapshots of simulated subglacial drainage structure. Snowline is contoured in bold. (a) 31 May 2000 (day 152). (b) 30 July 2000 (day 212).

future development of this aspect of the modelling is to introduce an anisotropic hydraulic conductivity tensor; in the limit that no ground-water transport is permitted perpendicular to the geologic strike, subsurface catchment structure would be profoundly affected.

\subsection{Time-dependent hydrology}

Realistic melt-season representations of Vatnajökull hydrology require time-evolving forcing and response. Making use of the temperature record in Figure 3 and DDFs computed in Equations (18) and (19), we can simulate spatial evolution of the subglacial drainage system (Fig. 8). For simplicity, this simulation does not include ground-water drainage or meltwater produced by geothermal heat sources beneath western Vatnajökull, and assumes that water originating above the ELA does not reach the bed.

In all time-dependent simulations, we find large changes in the Brúarjökull catchment area in response to surface meltwater input. In early summer, the Brúarjökull subglacial catchment area extends $\sim 50 \mathrm{~km}$ interior from the northern glacier margin (Fig. 8a). As the snowline retreats, the fluid potential gradient created by incoming meltwater is sufficient to override the gentle elevation potential gradient. Consequently, water above the snowline is driven uphill and southward toward Breiðamerkurjökull and the hydraulic divide migrates in time (Fig. 8b). While this may be an artifact of oversimplifying the basal hydrology, we cannot
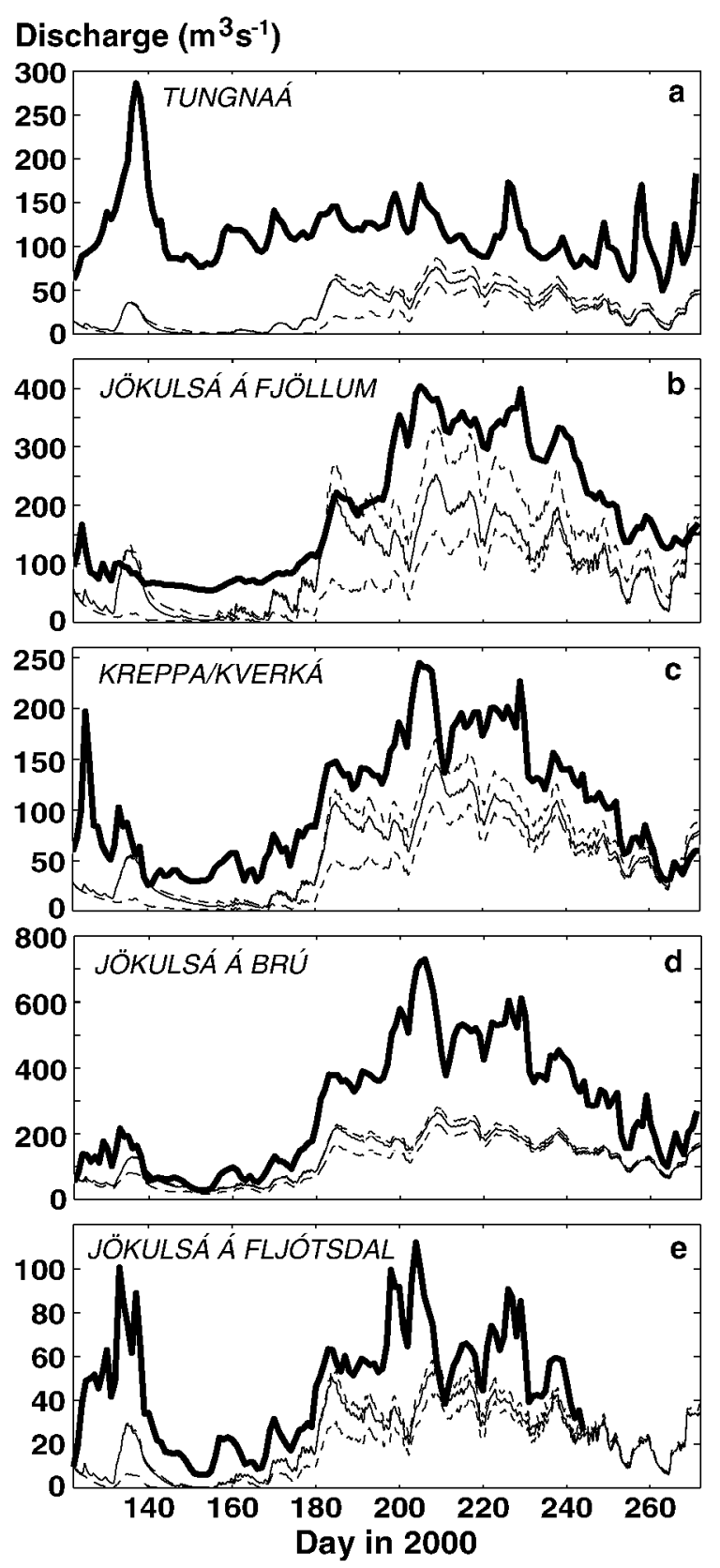

Fig. 9. Simulated glacial discharge (fine lines) compared to measured hydrographs (bold lines) for five outlet rivers, May-September 2000. The dashed lines represent end-member simulations, one assuming that all snowmelt and ice melt reaches the bed (upper curve) and one assuming that only ice melt reaches the bed (lower curve). Fine lines represent a compromise simulation in which snowmelt above the ELA is stored on the glacier surface. Data provided by H. H. Haraldsson, National Power Company of Iceland. (a) Tungnaá; (b) Jökulsá á Fjöllum; (c) Kreppa/Kverká; (d) Jöoulsáá Brú; (e) Jökulsá i Fljótsdal.

dismiss it entirely. We do not see any decisive indication of such divide migration in the western half of Vatnajökull where it could have serious implications for jökulhlaup routing. Surface elevation gradients are more severe in the west, so that meltwater-induced divide perturbations are less likely.

4.3.1. Discharge hydrographs, May-September 2000

Introducing a time-dependent surface melt rate permits the first estimates of seasonally varying glacial discharge 
Discharge fraction
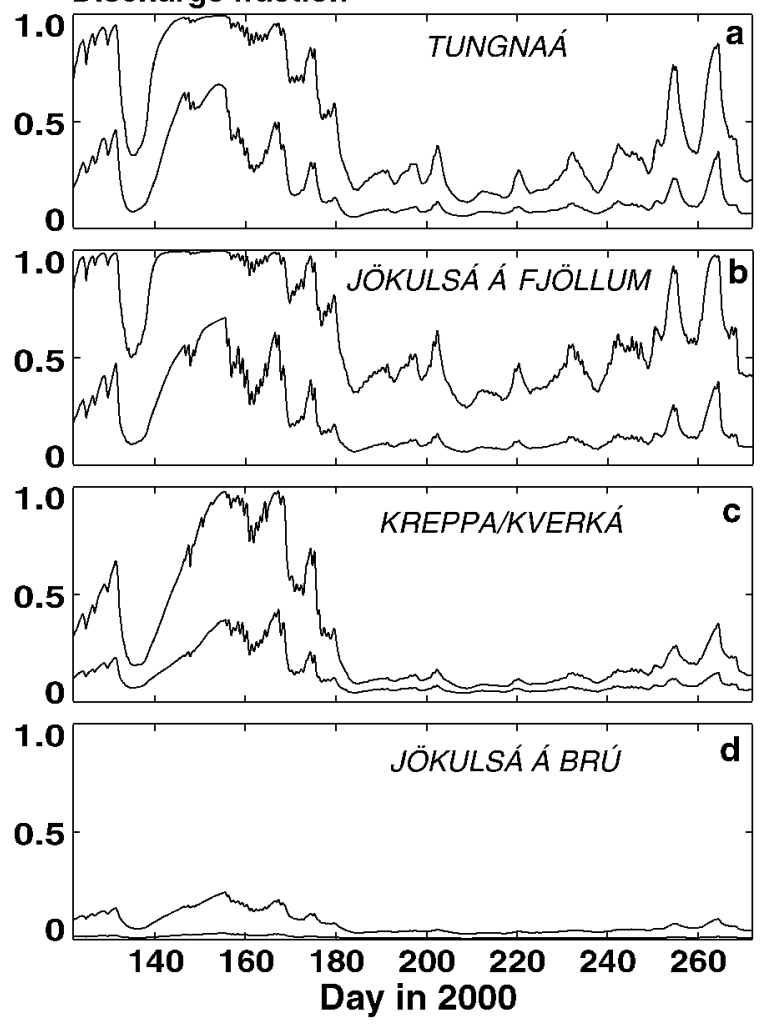

Fig. 10. Simulated fraction of glacial runoff routed through the aquifer, May-September 2000, for maximum (upper curves) and conservative (lower curves) ground-water models. (a) Tungnaá; (b) Jökulsá á Fjöllum; (c) Kreppa/Kverká; (d) Jökulsá á Brú.

contributions to Vatnajökull's outlet rivers. Figure 9 shows the mean daily measured discharge in five rivers (data of the National Power Company of Iceland) compared to the simulated glacial discharge. This crude approach to surface hydrology enables us to bracket a range of possibilities, while obviating the need for a complicated physical model.

Gauge measurements include significant non-glacial runoff and are variously affected by ground-water drainage. Hence, an unknown fraction of the total basin discharge is unaccounted for in the measurements (except in the case of Jökulsá í Fljótsdal). This uncertainty is probably largest for Jökulsá á Fjöllum. Calculations of glacial runoff by Björnsson and others (1998) for 1994/95 yielded mean values for Jökulsá á Fjöllum and Kaldakvísl that were higher than the gauge measurements.

Measured hydrographs for the smaller rivers Tungnaá, Kreppa/Kverká and Jökulsá í Fljótsdal have early-season snowmelt peaks (before day 150) that are comparable to or larger than peaks due to glacier ablation. In contrast, hydrographs for the large rivers Jökulsá á Fjöllum and Jökulsá á Brú are dominated by late-season discharge. Except in the river Tungnaá, the largest amplitude fluctuations in both simulated and observed hydrographs occur on seasonal time-scales, followed by fluctuations on 10-20 day timescales. Fluctuations on the diurnal time-scale are by far the smallest for both simulated and observed records (personal communication from H. H. Haraldsson, 2001), though it is not shown in the measurements. For all but Jökulsá á Brú, the glacial component of basin discharge generally increases from early to late melt season. The variability structure in the simulated records is similar to that in the observations, with most simulated peaks appearing to correlate with peaks in the observations. This is not necessarily expected, considering the simplistic method used to construct the surface forcing and the fact that summer precipitation is not included in the model.

Hydrographs simulated using the minimum model (lower dashed line in each panel of Fig. 9) show little earlyseason glacial discharge because we assume snowmelt does not contribute to runoff. Maximum and compromise models agree well in the early season, because they differ only in their treatment of snow above the ELA. Minimum and compromise models converge in the late season, when most of the runoff is derived from ice ablation. The discrepancy between end-member simulations for each river reveals the sensitivity of the respective drainage basins to snow hydrology, with Jökulsá á Fjöllum being the most sensitive to snowmelt routing, and Jökulsá á Brú the least. This sensitivity is a direct reflection of glacier surface hypsometry, with more sensitive basins having a larger fraction of their total area at high elevation.

To gauge the effect of ground-water drainage on glacier discharge as presented in Figure 9, we briefly reintroduce the coupled model. The simulated glacier discharge fraction routed through the aquifer $\left(Q^{\mathrm{a}} /\left(Q^{\mathrm{a}}+Q^{\mathrm{s}}\right)\right)$ is plotted in Figure 10 for ground-water maximum $\left(n^{\mathrm{a}} d^{\mathrm{a}}=50 \mathrm{~m}, K^{\mathrm{a}}=10^{-2}\right.$ $\left.\mathrm{ms}^{-1}\right)$ and conservative $\left(n^{\mathrm{a}} d^{\mathrm{a}}=25 \mathrm{~m}, K^{\mathrm{a}}=10^{-3} \mathrm{~ms}^{-1}\right)$ models. The quantity $Q^{\mathrm{a}} /\left(Q^{\mathrm{a}}+Q^{\mathrm{s}}\right)$ is predicted by the model to be highest in the early season and lowest during the peak melt season between days 180 and 250. The prominent dip preceding day 140 represents the arrival of snowmelt. In the conservative case (lower curves, Fig. 10), ground-water discharge comprises $>60 \%$ of the early-season glacier runoff in Jökulsá á Fjöllum and Jökulsá á Brú, and less than 10\% during the peak melt season for all basins. With the groundwater maximum model, $Q^{\mathrm{a}} /\left(Q^{\mathrm{a}}+Q^{\mathrm{s}}\right)$ is generally higher and more variable, especially in Jökulsá á Fjöllum where ground-water comprises $25-100 \%$ of the discharge. Determination of this ground-water component is prerequisite to a rigorous quantification of glacially derived discharge in rivers fed by Vatnajökull. This is a challenging task given the potentially continuous exchange of surface and subsurface water in these drainage basins.

\section{SUMMARY AND GONGLUSIONS}

A simple two-layer physical model of drainage under Vatnajökull has facilitated new insight into its basal hydrology and water budget. Our results complement existing studies of Vatnajökull by providing a physical link between the surface mass-balance distribution and glacier runoff.

Steady-state simulations of Vatnajökull suggest a summer 2000 mean discharge of $\sim 1350 \mathrm{~m}^{3} \mathrm{~s}^{-1}$, compared to a 1999/ 2000 annual mean of $\sim 570 \mathrm{~m}^{3} \mathrm{~s}^{-1}$. Geothermally derived meltwater is predicted by the model to account for approximately $5 \%$ of the mean annual glacier discharge. Modelled discharge provenance of Vatnajökull's major outlet rivers is roughly consistent with prior estimates based on mass balance and a statically derived subglacial catchment structure. While this reflects the similarity in subglacial flow directions implied by the two methods, the overall basal drainage structures appear markedly different because the distribution of surface meltwater is accounted for in the physical model.

Brúarjökull, Skeiðarárjökull and Breiðamerkurjökull 
appear to be the most hydrologically active drainage basins. All three glaciers occupy low-lying areas of the bed and have gently sloping surfaces. Simulations predict an early and ultimately extensive snowline retreat on these glaciers, with correspondingly high basal water fluxes. Low subglacial effective pressures are expected in these basins, at least prior to the seasonal development of conduit networks, suggesting favourable conditions for glacier sliding and sediment deformation. In steady-state simulations forced by 2000 mean summer melt rates, the zero effective-pressure contour resembles the perimeter of surge-affected areas in these three glacier basins. Dyngjujökull (feeding the river Jökulsá á Fjöllum) appears to be the most hydrologically complex drainage basin, exhibiting the highest sensitivities to geothermally derived meltwater, subsurface groundwater loss and surface snowmelt routing.

We estimate that the ground-water system beneath western Vatnajökull evacuates up to $\sim 30 \%$ of glacier discharge annually. In drainage basins feeding the rivers Hverfisfljót, Skaftá, Tungnaá, Kaldakvísl and Jökulsá á Fjöllum, groundwater may account for $70-80 \%$ of the annual discharge. Although hydraulic anisotropy is neglected in this study, regional-scale ground-water transport is nevertheless aligned with the southwest-northeast strike of subglacial geologic formations. Using reference model parameters, we calculate the mean annual ground-water discharge from Vatnajökull for the balance year 2000 to be $\sim 145 \mathrm{~m}^{3} \mathrm{~s}^{-1}$, which falls within Sigurðsson's (1990) estimate of $130-220 \mathrm{~m}^{3} \mathrm{~s}^{-1}$ for the total ground-water runoff from Iceland's four largest ice caps.

Our results highlight possible topics of interest for future field investigations of Vatnajökull, including (1) discharge with chemical signatures indicative of basally derived meltwater in rivers other than Skaftá and Skeiðará, (2) indications of ground-water emergence beneath glacier margins in western Vatnajökull, and (3) evidence for subglacial hydraulic divide migration between Brúarjökull and Breiðamerkurjökull during the melt season. Hydraulic divide stability in western Vatnajökull, where jökulhlaups initiate, remains an open question. To address this issue and its implications for jökulhlaup routing requires a model that includes a better subgrid representation of drainage-system evolution and a proper treatment of subglacial lakes.

\section{ACKNOWLEDGEMENTS}

G. Flowers gratefully acknowledges the Science Institute, University of Iceland, for its hospitality during her postdoctoral tenure there. She was supported by the U.S. National Science Foundation under the International Research Fellow Awards Program (award No. 0000-425). Mass-balance data collection was sponsored by the National Power Company and the Road Authority of Iceland, in conjunction with the European Union (Framework IV - Environment and Climate, TEMBA 1996-97, ICEMASS 1998-2000). Radio-echo data have been collected over many years, with funding from the National Power Company, Icelandic Road Authority, Icelandic Research Council and Research Fund of the University of Iceland. H. H. Haraldsson of the National Power Company of Iceland provided all the river discharge data in this paper. We wish to acknowledge the field volunteers, especially the members of the Icelandic Glaciological Society. The manuscript benefited from the careful reviews of T. Schuler, A. G. Fountain and J. S. Walder.

\section{REFERENGES}

Arnold, N., K. Richards, I. Willis and M. Sharp. 1998. Initial results from a distributed, physically based model of glacier hydrology. Hydrol. Processes, 12, 191-219.

Björnsson, H. 1974. Explanation of jökulhlaups from Grímsvötn, Vatnajökull, Iceland. Fökull, 24, 1-26.

Björnsson, H. 1976. Subglacial water reservoirs, jökulhlaups and volcanic eruptions. Fökull, 25, 1975, 1-14.

Björnsson, H. 1978. The cause of jökulhlaups in the Skaftá river, Vatnajökull. Jökull, 27, 1977, 71-78.

Björnsson, H. 1982. Drainage basins on Vatnajokull mapped by radio echo soundings. Nord. Hydrol., 13(4), 213-232.

Björnsson, H. 1986a. Delineation of glacier drainage basins on western Vatnajökull. Ann. Glaciol., 8, 19-21.

Björnsson, H. 1986b. Surface and bedrock topography of ice caps in Iceland, mapped by radio echo-sounding. Ann. Glaciol., 8, 11-18.

Björnsson, H. 1988. Hydrology of ice caps in volcanic regions. University of Iceland, Societas Scientiarum Islandica. (Vísindafélag Íslendinga [Science in Iceland] 45.)

Björnsson, H. 1992. Jökulhlaups in Iceland: prediction, characteristics and simulation. Ann. Glaciol., 16, 95-106.

Björnsson, H. 1998. Hydrological characteristics of the drainage system beneath a surging glacier. Nature, 395(6704), 771-774.

Björnsson, H. and P. Einarsson. 1991. Volcanoes beneath Vatnajökull, Iceland: evidence from radio echo-sounding, earthquakes and jökulhlaups. Fökull, 40, 1990, 147-168.

Björnsson, H. and H. Kristmannsdóttir. 1984. The Grímsvötn geothermal area, Vatnajökull, Iceland. Jökull, 34, 25-50.

Björnsson, H., F. Pálsson, M.T. Guðmundsson and H. H. Haraldsson. 1998 Mass balance of western and northern Vatnajökull, Iceland, 1991-1995. Jökull, 45, 35-58.

Björnsson, H., F. Pálsson, M.T. Gudmundsson and G. E. Flowers. 2001. The extraordinary 1996 jökulhlaup from Grímsvötn, Vatnajökull, Iceland. [Abstract.] Eos, 82(47), Fall Meeting Supplement, F528.

Boulton, G. S. and R. C. A. Hindmarsh. 1987. Sediment deformation beneath glaciers: rheology and geological consequences. F. Geophys. Res., 92(B9), 9059-9082.

Braithwaite, R. J. and O. B. Olesen. 1989. Calculation of glacier ablation from air temperature, West Greenland. In Oerlemans, J., ed. Glacier fluctuations and climatic change. Dordrecht, etc., Kluwer Academic Publishers, 219-233.

Bredehoeft, J. D. and G. F. Pinder. 1970. Digital analysis of areal flow in multiaquifer groundwater systems: a quasi three-dimensional model. Water Res. Res., 6(3), 883-888.

Clarke, G. K. C. 1987. Subglacial till: a physical framework for its properties and processes. 7. Geophys. Res., 92(B9), 9023-9036.

Fletcher, C. A. J. 1991. Computational techniques for fluid dynamics. Vol. 1. Fundamental and general techniques. Springer-Verlag, New York.

Flóvenz, Ó. G. and K. Sæmundsson. 1993. Heat flow and geothermal processes in Iceland. Tectonophysics, 225(1-2), 123-138.

Flowers, G. E. 2000. A multicomponent coupled model of glacier hydrology. (Ph.D. thesis, University of British Columbia.)

Flowers, G. E. and G. K. C. Clarke. 2002. A multicomponent coupled model of glacier hydrology: 1. Theory and synthetic examples. 7. Geophys. Res., 107(B11). (10.1029/2001JB001122.)

Fowler, A. C. 1999. Breaking the seal at Grímsvötn, Iceland. f. Glaciol., $45(151), 506-516$

Freeze, R. A. and J. A. Cherry. 1979. Groundwater. Englewood Cliffs, NJ, Prentice-Hall.

Fuller, S. and T. Murray. 2002. Sedimentological investigations in the forefield of an Icelandic surge-type glacier: implications for the surge mechanism. Quat. Sci. Rev., 21 (12-13), 1503-1520.

Gudmundsson, M.T., F. Sigmundsson and H. Björnsson. 1997. Ice--volcano interaction of the 1996 Gjálp subglacial eruption, Vatnajökull, Iceland. Nature, 389(6654), 954-957.

Hubbard, B. P., M. J. Sharp, I. C. Willis, M. K. Nielsen and C. C. Smart 1995. Borehole water-level variations and the structure of the subglacial hydrological system of Haut Glacier d'Arolla, Valais, Switzerland. F. Glaciol., 41(139), 572-583.

Iverson, N. R., R. W. Baker, R. LeB. Hooke, B. Hanson and P. Jansson. 1999. Coupling between a glacier and a soft bed. I. A relation between effective pressure and local shear stress determined from till elasticity. F. Glaciol., 45(149), 31-40.

Jóhannesson, H., K. Sæmundsson and S. Jakobsson. 1990. Geological map of Iceland. Reykjavík, Icelandic Museum of Natural History and Iceland Geodetic Survey. (Sheet 6.)

Jóhannesson, T. 2002. Propagation of a subglacial flood wave during the initiation of a jökulhlaup. Hydrol. Sci. F., 47(3), 417-434. 
Jóhannesson, T., O. Sigurdsson, T. Laumann and M. Kennett. 1995. Degreeday glacier mass-balance modelling with applications to glaciers in Iceland, Norway and Greenland. f. Glaciol., 41(138), 345-358.

Kamb, B. 1970. Sliding motion of glaciers: theory and observation. Rev. Geophys. Space Phys., 8(4), 673-728.

Kamb, B. and 7 others. 1985. Glacier surge mechanism: 1982-1983 surge of Variegated Glacier, Alaska. Science, 227(4686), 469-479.

Kavanaugh, J. L. 2000. Hydromechanical behaviour of a surge-type glacier: Trapridge Glacier, Yukon Territory, Canada. (Ph.D. thesis, University of British Columbia.)

Laumann, T. and N. Reeh. 1993. Sensitivity to climate change of the mass balance of glaciers in southern Norway. 7. Glaciol., 39(133), 656-665.

Nye, J. F. 1976. Water flow in glaciers: jökulhlaups, tunnels and veins. F. Glaciol., 17(76), 181-207.

Pálsson, F., H. Björnsson, G. P. Eydal and H. H. Haraldsson. 2001. Vatnajökull: mass balance, meltwater drainage and surface velocity of the glacial year 1999-2000. Reykjavík, University of Iceland, Science Institute; National Power Company of Iceland. (Report \#RH-01-2001.)

Patankar, S.V. 1980. Numerical heat transfer and fluid flow. New York, Hemisphere Publishing. (D. Reidel Publishing Co.)

Paterson, W. S. B. 1994. The physics of glaciers. Third edition. Oxford, etc., Elsevier.

Press, W. H., S. A. Teukolsky, W.T. Vetterling and B. P. Flannery. 1992. Numerical recipes in FORTRAN: the art of scientific computing. Second edition. Cambridge, Cambridge University Press.
Raymond, C. F., R. J. Benedict, W. D. Harrison, K. A. Echelmeyer and M. Sturm. 1995. Hydrological discharges and motion of Fels and Black Rapids Glaciers, Alaska, U.S.A.: implications for the structure of their drainage systems. F. Glaciol., 41(138), 290-304

Roberts, M.J., A. J. Russell, F. S. Tweed and Ó. Knudsen. 2000. Correspondence. Rapid sediment entrainment and englacial deposition during jökulhlaups. F. Glaciol., 46(153), 349-351.

Shreve, R. L. 1972. Movement of water in glaciers. f. Glaciol., 11(62), 205-214. Shreve, R. L. 1985. Esker characteristics in terms of glacier physics, Katahdin esker system, Maine. Geol. Soc. Am. Bull., 96(5), 639-646.

Sigurðsson, F. 1990. Groundwater from glacial areas in Iceland. Fökull, 40, 119-146.

Spring, U. and K. Hutter. 1981. Numerical studies of jökulhlaups. Cold Reg. Sci. Technol., 4(3), 227-244.

Tarboton, D. G. 1997. A new method for the determination of flow directions and upslope areas in grid digital elevation models. Water Res. Res., 33(2), 309-319.

Thorarinsson, S. 1969. Glacier surges in Iceland with special reference to the surges of Brúarjökull. Can. F. Earth Sci., 6(4), Part 2, 875-882.

Tulaczyk, S. M., B. Kamb and H. F. Engelhardt. 2000. Basal mechanics of Ice Stream B, West Antarctica. I. Till mechanics. F. Geophys. Res., 105(B1), 463-481.

Zevenbergen, L.W. and C. R. Thorne. 1987. Quantitative analysis of land surface topography. Earth Surf. Processes Landforms, 12(1), 47-56.

MS received 18 March 2002 and accepted in revised form 14 January 2003 